\title{
Mapping of quantitative adult plant field resistance to leaf rust and stripe rust in two European winter wheat populations reveals co-location of three QTL conferring resistance to both rust pathogens
}

\author{
Maria Buerstmayr $\cdot$ Lydia Matiasch $\cdot$ Fabio Mascher $\cdot$ Gyula Vida $\cdot$ \\ Marianna Ittu • Olivier Robert • Sarah Holdgate · Kerstin Flath • \\ Anton Neumayer $\cdot$ Hermann Buerstmayr \\ Received: 11 March 2014 / Accepted: 13 July 2014 / Published online: 12 August 2014 \\ (C) The Author(s) 2014. This article is published with open access at Springerlink.com
}

\begin{abstract}
Key message We detected several, most likely novel QTL for adult plant resistance to rusts. Notably three QTL improved resistance to leaf rust and stripe rust simultaneously indicating broad spectrum resistance QTL.

Abstract The rusts of wheat (Puccinia spp.) are destructive fungal wheat diseases. The deployment of resistant cultivars plays a central role in integrated rust disease management. Durability of resistance would be preferred, but is difficult to analyse. The Austrian winter wheat cultivar Capo was released in the 1989 and grown on a large acreage during more than two decades and maintained a good level of quantitative leaf rust and stripe rust resistance. Two bi-parental mapping populations: Capo $\times$ Arina and Capo $\times$ Furore were tested in multiple environments for severity of leaf rust and
\end{abstract}

Communicated by Thomas Miedaner.

Electronic supplementary material The online version of this article (doi:10.1007/s00122-014-2357-0) contains supplementary material, which is available to authorized users.

M. Buerstmayr · L. Matiasch · H. Buerstmayr $(\bowtie)$

Department for Agrobiotechnology Tulln, BOKU-University

of Natural Resources and Life Sciences Vienna, Konrad Lorenz

Str. 20, Tulln 3430, Austria

e-mail: hermann.buerstmayr@boku.ac.at

F. Mascher

Agroscope Changins-Wädenswil Research Station ACW,

1260 Nyon, Switzerland

G. Vida

Agricultural Research Institute of the Hungarian Academy

of Sciences, Martonvásár 2462, Hungary

M. Ittu

National Agricultural Research Development Institute Fundulea,

915200 Fundulea, Romania stripe rust at the adult plant stage in replicated field experiments. Quantitative trait loci associated with leaf rust and stripe rust severity were mapped using DArT and SSR markers. Five QTL were detected in multiple environments associated with resistance to leaf rust designated as $Q L$ rifa- $2 A L$, QLrifa-2BL, QLrifa-2BS, QLrifa-3BS, and QLrifa-5BL, and five for resistance to stripe rust QYrifa-2AL, QYrifa2BL, QYrifa-3AS, QYrifa-3BS, and QYrifa-5A. For all QTL apart from two (QYrifa-3AS, QLrifa-5BL) Capo contributed the resistance improving allele. The leaf rust and stripe rust resistance QTL on 2AL, 2BL and 3BS mapped to the same chromosome positions, indicating either closely linked genes or pleiotropic gene action. These three multiple disease resistance QTL (QLrifa-2ALQYrifa-2AL, QLrifa.2BL/QYrifa$2 B L, Q L$ rifa-3BS/QYrifa.3BS) potentially contribute novel resistance sources for stripe rust and leaf rust. The long-lasting resistance of Capo apparently rests upon a combination of several genes. The described germplasm, QTL and markers are applicable for simultaneous resistance improvement against leaf rust and stripe rust.

O. Robert

Bioplante, 3 Rue Florimond Desprez, BP41, 59242 Cappelle-en-

Pévèle, France

S. Holdgate

RAGT Seeds, Grange Road, Ickleton, Essex CB10 1TA, UK

Present Address:

S. Holdgate

NIAB, Huntingdon Road, Cambridge CB3 OLE, UK

K. Flath

Julius Kühn Institute, Federal Research Centre for Cultivated

Plants, 14532 Kleinmachnow, Germany

A. Neumayer

SAATZUCHT DONAU GmbH \& CoKG, Reichersberg 4981, Austria 


\section{Introduction}

Leaf rust (brown rust, Lr) and stripe rust (yellow rust, $\mathrm{Yr}$ ), caused by Puccinia triticina and P. striiformis f. sp. tritici, respectively, are major biotic threats in many wheat-growing regions of the world. Genetic control of rust diseases offers a cost-effective and environmental-friendly strategy to reduce losses in wheat. Resistance to rust diseases is either quantitative (horizontal, uniform, race-non-specific, stable, adult plant resistance) or qualitative (vertical, differential, race-specific, unstable, seedling resistance) (Van der Plank 1963, 1968). Generally, race-specific resistances are governed by major genes, which confer complete resistance and are highly effective through the entire life cycle of the host plants. These genes usually initiate a hypersensitive response, leading to a rapid cell death upon infection by a pathogen race that carries a matching avirulence gene (Flor 1956; Heath 2000). Rust pathogens are notorious for their rapid adaptation to such genes. Consequently, cultivars that rely on race-specific genes may become susceptible within a few years (Priyamvada et al. 2011; Kolmer 2013). Stripe rust pathotypes with complex virulence profiles, increased aggressiveness and extended adaption to previously unfavorable environments have evolved (Hovmøller 2008; Milus 2009).

Currently, more than 70 formally and ten temporarily designated $L r$ genes and more than 50 formally and around 40 temporarily designated $\mathrm{Yr}$ genes have been described (McIntosh et al. 2012). Most of these genes confer race-specific resistance (Lin and Chen 2007; Bolton 2008). Only a few of these extensively used genes remained effective over a long period (Singh et al. 1997; Chen 2007; Lowe 2011a; Ren et al. 2012). In contrast to race-specific resistance genes, the combination of several partial, race-non-specific resistances constitutes an alternative by providing more durable resistance. These genes usually contribute incomplete, minor to intermediate quantitative, partial resistance due to reduced receptivity, increased latent period, smaller and fewer uredinia (Ohm and Shaner 1976; Parlevliet 1985). Partial resistance genes are generally more effective at adult plant stages and are also termed adult plant resistance (APR) genes, although not all APR genes are race-non-specific (McCallum et al. 2012). Breeding for durable resistance is an important but difficult task. Johnson (1981) described durable resistance as resistance that remains effective when deployed over an extensive acreage and time in an environment favorable for the disease. Therefore, durability can be confirmed only retrospectively over the course of time. Three rust resistance gene complexes are in accordance with the definition of durable resistance, Lr34/Yr18/Pm38 (McIntosh 1992; Spielmeyer et al. 2005; Krattinger et al. 2009; Lagudah et al. 2009), Lr46/Yr29/Pm39 (Singh et al. 1998; William et al. 2003; Lillemo et al. 2008) and Sr2/Yr30
(McIntosh 1995; Singh et al. 2001; Rehman et al.2013). All together they confer non-hypersensitive, slow-rusting, partial type of resistance. Partial resistance genes are of great interest as sources of potentially more durable resistance, although not all partial resistance genes are durable (Johnson 1992). This has initiated a number of QTL studies, which have reported the detection of numerous QTL. Rosewarne et al. (2013) provides an update review about QTL for stripe rust in wheat published during the last 10 years, summarizing more than 140 QTL assigned to 49 chromosomal locations. Although many of these QTL may be redundant, it illustrates a great genetic diversity for this trait. Partial resistance genes have also been found for leaf rust. To date, more than 20 QTL have been described (William et al.1997; 2006; Nelson et al. 1997; Faris et al. 1999; Messmer et al. 2000; Suenaga et al. 2003; Schnurbusch et al. 2004; Navabi et al. 2005; Xu et al. 2005a, b; Rosewarne et al. 2008; Maccaferri et al. 2008; 2010; $\mathrm{Li}$ et al. 2009; Chu et al. 2009; Singh et al. 2009). Partial resistance genes are additive in their effect and lead to enhanced resistance when combined. Under high disease pressure a combination of 4-5 such genes is required to provide sufficiently high levels of resistance (Singh et al. 2000a; Singh et al. 2011a). The Austrian winter wheat cultivar Capo was released in1989 and has been grown on a large-acreage in Austria, Hungary, Rumania and Slovakia, as well as Germany and France since then. Taken together, Capo has been grown on more than one Million ha since its release. And it is still the most important bread-making quality winter wheat in Austria (BAES 2013). Capo is a good yielding, high quality winter wheat with medium to good resistance to various diseases. It combines high resistance to stripe rust with moderate resistance to leaf rust that has remained stable since it was released. Previous screenings for resistance to leaf rust rated Capo susceptible at the seedling stage, but resistant at adult plant stage in field tests, indicating that it carries effective APR (Winzeler et al. 2000). Similarly, Pathan and Park (2006) verified the presence of unknown APR $L r$ gene(s) in addition to the seedling resistance gene Lr13. Multi-pathotype analysis for stripe rust identified seedling resistance gene $Y r 27$ and additional unknown seedling resistance gene(s) (Pathan et al. 2008). Our study uses two independent mapping populations to characterize the genetics of resistance of Capo to both leaf rust and stripe rust at the adult plant stage.

\section{Materials and methods}

Plant material

Two mapping populations comprising 233 and 201 recombinant inbred lines (RILs) were developed by single seed descent from crosses of Capo and Arina (CA) and of 
Capo and Furore (CF), respectively. Capo (Diplomat/ Purdue5517//Extrem/HP3517 (= Pokal/Martin)) is a high quality winter wheat cultivar developed by Probstdorfer Saatzucht, Austria. Arina (Moisson/Zenith) is a high quality winter wheat cultivar developed by Agroscope, Switzerland and was released in 1981. Arina is highly susceptible in field tests to leaf rust and susceptible to stripe rust. Furore (Carolus//Pokal/Martin (one parent is a sister line of Capo)) is a quality winter wheat cultivar developed by Probstdorfer Saatzucht, Austria. It is moderately to highly susceptible to leaf rust and highly susceptible to stripe rust.

Multi-pathotype screening at seedling stage with a set of 20 different pathotypes of $P$. triticina, which were in total virulent to $L r 1, L r 2 a, L r 2 c, L r 3 a, L r 3 b g, L r 3 k a, 10, L r 11$, Lr13, Lr 4a, Lr 5, Lr 6, Lr17a, Lr17b, Lr20, Lr23, Lr26, $L r 27+L r 31$, postulated LrI3 for both, Capo and Arina (Park et al. 2001). Field tests using either pathotypes virulent against genes $L r 1, L r 2 c, L r 3 a, L r 3 b g, L r 3 k a, L r 10, L r 13$, Lr14a, Lr16, Lr17b, Lr20, Lr23, Lr24, Lr26 (Pathan and Park 2006) or local races of unknown pathogenicity (Winzeler et al. 2000) ascertained high adult plant field resistance for Capo and susceptibility for Arina. Capo and Arina were screened for seedling resistance with 13 different pathotypes of $P$. striiformis, which were in total virulent against $Y r 1, Y r 2$, $Y r 3, Y r 4, Y r 6, Y r 7, Y r 8, Y r 9, Y r 17, Y r 27, Y r 32, Y r A, Y r S D$, $Y r S O$ and $Y r S P$ (Pathan et al. 2008). This study identified the seedling resistance gene $Y r 27$ and additional resistance(s) of uncertain identity in Capo and the absence of any seedling resistance gene in Arina. Capo and Arina displayed high levels of resistance at adult plant growth stages in field nurseries, when inoculated with pathotypes virulent to $\mathrm{Yr} 2, \mathrm{Yr} 3, \mathrm{Yr}$, Yr6, Yr7, YrSD, YrSO, YrA (Pathan et al. 2008).

\section{Field experiments}

\section{Leaf rust experiments}

233 RILs of population CA and 201 RILs of population CF, the parents and several control lines were tested in different experimental sites over several years. Population CA was evaluated in eight field trials conducted in Austria at Tulln, Probstdorf, Rust, Schmida, and at Fundulea/Romania, Martonvásár/Hungary in 2008 and at Tulln and Rust in 2009. Population CF was tested in four experiments, carried out at Tulln in 2004, 2007 and 2008, and at Probstdorf in 2006. Trials were managed according to local practices of the respective locations. RILs were sown in single or double rows interspersed by a single spreader row. Experiments were artificially inoculated using a local bulk of urediniospores of unidentified pathotypes. Such spore bulks were usually collected in surrounding areas of the experimental sites in the previous season, and, therefore, represent the local pathotype population. Leaf rust epidemics were provoked by spraying or injecting a suspension of urediniospores on or into spreader rows/plants and planting diseased seedlings into spreader rows. The average percentage of leaf area of adult plants covered by leaf rust (leaf rust severity, LrS) was visually estimated according to the scale described by Moll et al. (1996). One or more ratings were done, the latest usually shortly before leaf senescence when the upper leaves were still green and scorable. Statistical analysis was carried out on data from the final disease rating when the disease was usually maximally spread. Information on locations, experimental designs, spreaders, inoculation techniques of individual trials is provided in Online Resource 1.

\section{Stripe rust experiments}

172 RILs of population CA and 201 RILs of population CF, the parents and several control lines were tested in different experimental sites over several years in altogether five respective six field trials. Stripe rust experiments of population CA were conducted at Tulln/Austria in 2011 and at Atzenbrugg/ Austria and Reichersberg/Austria, at Changins/Switzerland and at Cappelle-en-Pévèle/France in 2012. Population CF was evaluated at Reichersberg in 2009 and 2010, at Tulln in 2010 and 2011, and at Atzenbrugg and Changins in 2012. Subsets of 31 RILs of both populations were additionally tested in the United Kingdom at Cambridge and Ickleton in 2012. Agronomic practices followed local standards. Apart from the trial at Cambridge, all experiments were artificially inoculated. Pathotype or pathotype mixtures propagated on seedlings of susceptible genotypes in the greenhouse under controlled conditions were collected and used for inoculation. The highly aggressive Warrior race was already included in experiments Cappelle-en-Pévèle/France in 2012 and United Kingdom at Ickleton in 2012 (see Online Resource 2). All experiments included a combination of pathotypes, which were, among others, virulent against resistance genes [1, 2, 3, $6,7,8,9,17,25,32]$, although no single pathotype had this specific virulence combination. Experiments were inoculated by spraying urediniospore suspensions onto test lines and/or transplanting infected seedlings into the trials. Information on individual experiments, inoculation methods, virulence profiles of applied pathotypes and disease evaluation methods are summarized in Online Resource 2. The average percentage of leaf tissue of adult plant covered by stripe rust (stripe rust severity, YrS) was visually estimated according to the scale described by Moll et al. (1996) when the disease was maximally spread. Differently scored experiments were converted into percentage values.

\section{Statistical analysis of field experiments}

Analysis of variance (ANOVA) and correlation of field data were calculated in SAS/STAT version 9.2 (SAS Institute 
Inc 2008). Distribution of residuals was tested for normality using PROC UNIVARIATE applying the KolmogorovSmirnov statistic. A Logit transformation was chosen to adjust the stripe rust data to achieve near normality and the statistical analysis of the stripe rust experiments were done on the Logit transformed and the non-transformed datasets. For stripe rust, the presented first order parameters (e.g. means, histograms, additive effects) were obtained from untransformed data, while second order statistics (ANOVAs, broad sense heritability, correlation coefficients, LOD scores and percent explained variance by QTL) were calculated from the transformed data. Analysis of variance (ANOVA) was conducted using the general linear model (GLM) procedure, with all effects fixed. The effects of experiments, as a combination of year and location, replication within experiments, genotype, and genotype-byexperiment interaction were calculated. Broad-sense heritability was estimated from variance components with the equation $H=\sigma_{\mathrm{d}}^{2}\left(\sigma_{\mathrm{G}}^{2}+\sigma_{\mathrm{G}}^{2} / \ell_{\mathrm{E}}+\sigma_{\mathrm{E}}^{2}\right.$ en $)$, where $\sigma_{\mathrm{G}}^{2}=$ genotypic variance, $\sigma_{\mathrm{G} \times \overline{\mathrm{E}}}^{2}$ genotype-by-experiment interaction variance, $\sigma_{\mathrm{E}}^{2}=$ error variance, $e=$ number of experiments, and $n=$ number of replications (Nyquist 1991). For the estimation of broad-sense heritability, all effects were considered random. Spearman rank-correlation coefficients were estimated for all pair-wise experiment combinations and correlation between stripe rust and leaf rust severity was estimated from means over all experiments.

\section{Molecular marker analysis and map construction}

High-quality genomic DNA was isolated from pooled samples of young leaves from ten plants of each RIL and of the parental lines using the cetyl-trimethyl-ammonium bromide (CTAB) method of Saghai-Maroof et al. (1984). Diversity array technology (DArT) marker assays were performed on parents and on 171 and 178 RILs of populations CA and CF, respectively, by Triticarte Pty. Ltd (Canberra, Australia; http://www.triticarte.com.au). Furthermore, SSR (simple sequence repeat) markers were added primarily at genomic region where QTL were detected or suspected. Six BARC (Song et al. 2005), 36 GWM (Roeder et al. 1998) and 3 WMC (Somers et al. 2004) markers were used in population CA and 7 GWM, 5 BARC and 2 WMC markers in population $\mathrm{CF}$.

Map construction of CA and CF populations was carried out using CarthaGene 1.2-LKH (de Givry et al. 2005). Marker data of both populations were analyzed simultaneously using the command dsmergor. This produces consensus data sets sharing marker order, but separate parameter estimates with per dataset distances (CarthaGene user manual). Apparently allelic markers were removed leaving a single representative. Distances between markers in $\mathrm{cM}$ were calculated based on the Kosambi mapping function implemented in CarthaGene. Linkage groups were assigned to chromosomes according to information from Triticarte (http://www.triticarte.com.au) and allocated to a specific chromosomal arm by comparing the arrangement of markers with maps published by Marone et al. (2012), Francki et al. (2009), Mantovani et al. (2008), Peleg et al. (2008), Crossa et al. (2007) and Akbari et al. (2006) and maps available in the GrainGenes database (http://wheat.pw.usda. gov/ggpages/maps.shtml).

\section{QTL analysis}

QTL calculations were carried out with $\mathrm{R}$ version 3.0.2 (R Development Co re Team 2011) using the R/qtl package 1.28-19-12 (Broman et al. 2003). Missing genotypic information was imputed using the multiple imputation method of Sen and Churchill (2001). Genome wide QTL searches were conducted for each experiment separately and for the overall means across all experiments. Interval mapping was performed using a single QTL genome scan and pairwise epistatic QTL interactions were calculated using a two dimensional QTL scan via Haley-Knott regression (Haley and Knott 1992). LOD significance thresholds of the respective trait and population for type I error rates of $\alpha<0.1, \alpha<0.05$ and $\alpha<0.01$ were determined by running 1000 permutations on the single and two dimensional QTL scan. Finally, a multiple QTL mapping (MQM) analysis was performed on the individual environments and on the overall means across environments. Trait and population specific MQM models were fitted including all significant QTL and QTL interactions. The overall fit of the full model against the null model was tested by ANOVA and the estimated additive effect and the percentage of phenotypic variance explained by each QTL were obtained from the MQM analysis. The QTL support interval criterion was determined using a LOD decrease of 1.5 from the maximum LOD position. Linkage groups and LOD bars were drawn with MapChart v2.2 (Voorrips 2002). No QTL analysis was performed on the subsets tested for YrS at Cambridge/GB and at Ickleton/GB. Lines of these sub-populations were grouped according their genotypic information by the number of QTL improving alleles and differences between the means of these groups were compared using the Duncan multiple range test.

\section{Results}

Trait variation and trait correlations

The field studies achieved various levels of infections for both leaf rust and stripe rust. Distribution of lines 

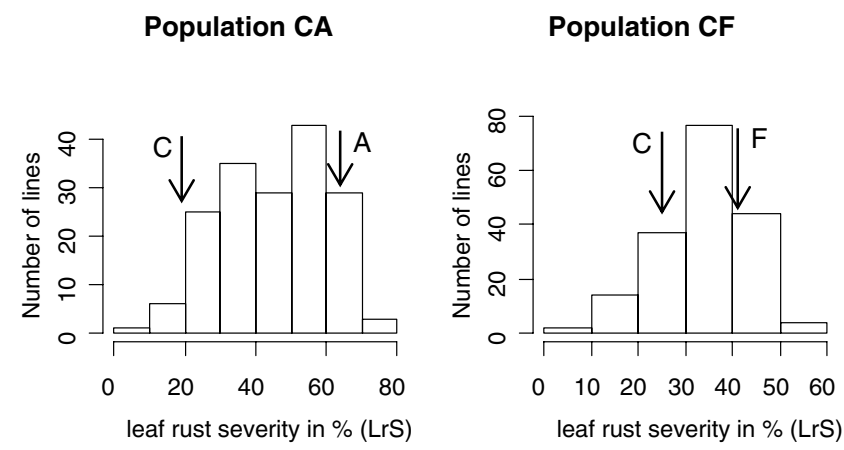

Fig. 1 Phenotypic variation in leaf rust and stripe rust severity of the averaged means across all experiments for population Capo $\times$ Arina $(\mathrm{CA})$ and Capo $\times$ Furore $(\mathrm{CF})$. Frequency distribution of RILs for

according their leaf rust and stripe rust severity of the averaged means across all experiments for population CA and $\mathrm{CF}$ are depicted in Fig. 1. The phenotypic frequency distribution for YrS differed significantly from normality for both populations $(p<0.001)$ and was skewed towards resistance. The phenotypic frequency distributions for LrS were more continuous $(p>0.01)$ and were slightly skewed towards susceptibility. The population means of the stripe rust experiments were in general lower than those of the leaf rust experiments. The susceptible parents Furore and Arina were consistently more diseased in all leaf rust experiments than the resistant parent Capo. The stripe rust scores for Capo were generally low (0-2.5 $\mathrm{YrS}$ ), with the exception of the experiment at Cambridge (30 YrS). Infection level of Capo varied from low to medium values (3-47 LrS) in the leaf rust experiments. This is shown in Table 1, where mean values of the parents, means and ranges of the populations and least significant differences of individual experiments are summarized. Spearman rank-correlations between experiments were all significantly different from zero and showed ranges from $r=0.58-0.83$ and $r=0.53-0.89$ for the stripe rust experiments and from $0.45-0.78$ and $0.39-0.73$ for the leaf rust experiments in population $\mathrm{CA}$ and $\mathrm{CF}$, respectively (Online Resource 3). Correlations between mean $\mathrm{LrS}$ and mean $\mathrm{YrS}$ were $r=0.58$ in population CA and $r=0.65$ in $\mathrm{CF}$.

ANOVA for stripe rust and leaf rust severity resulted in highly significant effects $(p<0.0001)$ for experiment, genotype and genotype $\times$ experiment interaction (Online Resource 4). The variation due to the genotypes was high compared to the genotype by experiment variances. This resulted in high heritability values. Broadsense heritabilities for means over all experiments were $H=0.93$ for $\mathrm{YrS}$ for both populations and were $H=0.84$ in the $\mathrm{CF}$ versus $H=0.89$ in the CA population for LrS (Tables 2, 3).
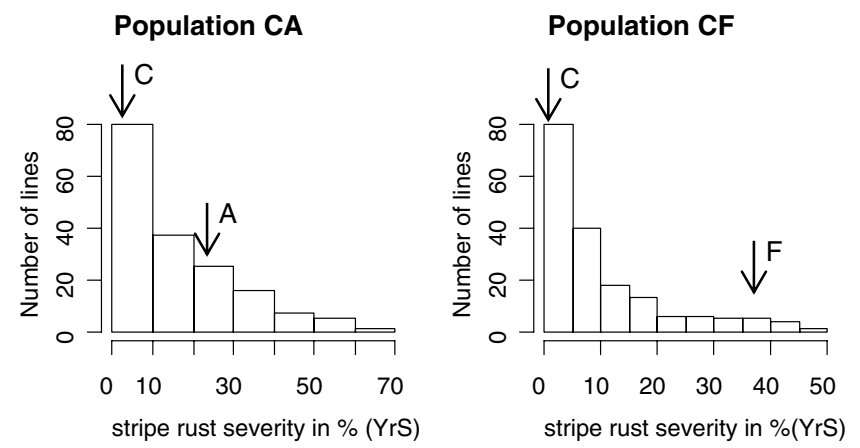

YrS (\%) and LrS (\%). Parental scores Capo (C), Arina (A), Furore (F) are indicated by arrows

\section{Linkage maps}

DArT and SSR markers generated a total of 674 and 710 polymorphic markers in population $\mathrm{CA}$ and $\mathrm{CF}$, respectively. The high number of redundant DArT markers reduced the final number of unique marker loci to 432 in the CA map and to 310 in the CF map, of which 129 markers were present in both populations. The total map length of population CA was 1,644 cM, resulting in an average distance of $3.8 \mathrm{cM}$. Markers fell into 34 linkage groups covering $635 \mathrm{cM}$ on genome A, $727 \mathrm{cM}$ on genome B and $256 \mathrm{cM}$ on genome D. Twenty-six cM could not be unambiguously assigned to a chromosome, no linkage group could be attributed to chromosome 4D. Capo and Furore are related cultivars, which is reflected in the relatively shorter total map length of $859 \mathrm{cM}$, with a $2.8 \mathrm{cM}$ average marker distance for CF population. Markers of population $\mathrm{CF}$ fell into 31 linkage groups covering $230 \mathrm{cM}$ on the A genome, $537 \mathrm{cM}$ on the $\mathrm{B}$ genome, $48 \mathrm{cM}$ on the D genome, whilst $44 \mathrm{cM}$ remained unassigned. All chromosomes were represented, but chromosomes on the D genome had lower marker coverage.

\section{QTL analysis}

For stripe rust experiments the analysis was run with both the transformed and non-transformed datasets. Basically the same results were obtained with only small differences in the calculated estimates of detected QTL. The results presented here refer to the transformed dataset. All QTL identified, their positions and statistical parameters for population CA and CF are summarized in Table 2 and Table 3, respectively. QTL identified in multiple experiments are depicted in Fig. 2 and boxplots of the effect of contrasting alleles at these QTL are illustrated in Fig. 3. LOD profiles of QTL are based on overall means, size of the QTL support intervals of the individual experiments are 
Table 1 Means of parents, mean, minimum and maximum values of populations, least significant differences at $\alpha<$ 0.05 (LSD) of stripe rust and leaf rust severity a subset of 31 lines, data not included in overall mean

\begin{tabular}{|c|c|c|c|c|c|c|c|c|}
\hline Trait & Country & Year & \multicolumn{2}{|l|}{ Parents } & Mean & Min & Max & LSD5\% \\
\hline \multicolumn{9}{|c|}{ Stripe rust severity $(\%)$} \\
\hline \multicolumn{3}{|c|}{ Population Capo $\times$ Furore } & Capo & Furore & & & & \\
\hline \multicolumn{3}{|l|}{ Overall mean } & 0.3 & 38.5 & 9.5 & 0 & 49 & 5.6 \\
\hline Reichersberg & AT & 2009 & 0 & 7.6 & 2.8 & 0 & 18 & 2.1 \\
\hline Reichersberg & AT & 2010 & 0 & 17.7 & 4.7 & 0 & 26 & 2.3 \\
\hline Tulln & AT & 2010 & 0.1 & 53.0 & 7.1 & 0 & 65 & 7.4 \\
\hline Tulln & AT & 2011 & 0 & 45.0 & 7.9 & 0 & 70 & 6.2 \\
\hline Atzenbrugg & AT & 2012 & 0.75 & 70.0 & 20.1 & 0 & 75 & 8.1 \\
\hline Changins & $\mathrm{CH}$ & 2012 & 0.75 & 37.5 & 16.5 & 0 & 55 & 4.9 \\
\hline Cambridge $^{\mathrm{a}}$ & GB & 2012 & 30 & 65.0 & 43.1 & 2.5 & 80 & 9.3 \\
\hline Ickleton $^{\mathrm{a}}$ & GB & 2012 & 0 & 50 & 15.7 & 0 & 63 & 7.1 \\
\hline \multicolumn{2}{|c|}{ Population Capo $\times$ Arina } & & Cаро & Arina & & & & \\
\hline \multicolumn{2}{|l|}{ Overall mean } & & 0.1 & 24.0 & 16.0 & 0 & 65 & 5.5 \\
\hline Tulln & AT & 2011 & 0 & 20.0 & 10.9 & 0 & 85 & 5.2 \\
\hline Atzenbrugg & AT & 2012 & 0 & 65.0 & 29.3 & 0 & 90 & 6.9 \\
\hline Reichersberg & AT & 2012 & 0.5 & 2.0 & 2.9 & 0 & 14 & 1.5 \\
\hline Cappelle & FR & 2012 & 0 & 10.0 & 19.9 & 0 & 75 & 5.2 \\
\hline Changins & $\mathrm{CH}$ & 2012 & 0 & 25.0 & 15.1 & 0 & 73 & 7.1 \\
\hline Cambridge $^{\mathrm{a}}$ & GB & 2012 & 30 & 45.0 & 33.0 & 12.5 & 55 & 11.5 \\
\hline Ickleton $^{\mathrm{a}}$ & GB & 2012 & 0 & 0.1 & 3.0 & 0 & 30 & 5.4 \\
\hline \multicolumn{9}{|c|}{ Leaf rust severity (\%) } \\
\hline \multicolumn{2}{|c|}{ Population Capo $\times$ Furore } & & Capo & Furore & & & & \\
\hline \multicolumn{2}{|l|}{ Overall mean } & & 25.5 & 41.6 & 34.7 & 6.5 & 53 & 7.5 \\
\hline Tulln & AT & 2004 & 7.0 & 33.3 & 22.0 & 1 & 45 & 6.8 \\
\hline Probstdorf & AT & 2006 & 47.5 & 57.5 & 53.5 & 4 & 80 & 5.5 \\
\hline Tulln & AT & 2007 & 20.0 & 28.0 & 24.2 & 5 & 50 & 10.0 \\
\hline Tulln & AT & 2008 & 27.5 & 47.5 & 38.8 & 4 & 60 & 7.2 \\
\hline Population Capc & $\times$ Arina & & Capo & Arina & & & & \\
\hline Overall mean & & & 18.9 & 67.7 & 43.2 & 4 & 70 & 8.7 \\
\hline Martonvásár & $\mathrm{HU}$ & 2008 & 20.0 & 90.0 & 60.1 & 0 & 100 & 11.6 \\
\hline Fundulea & $\mathrm{RO}$ & 2008 & 3.0 & 90.0 & 50.7 & 0 & 100 & - \\
\hline Schmida & AT & 2008 & 17.3 & 53.8 & 31.8 & 0 & 60 & 11.2 \\
\hline Probstdorf & AT & 2008 & 47.5 & 58.8 & 51.6 & 30 & 65 & 4.0 \\
\hline Rust & AT & 2008 & 16.9 & 60.0 & 45.3 & 5 & 70 & 9.4 \\
\hline Tulln & AT & 2008 & 3.0 & 26.5 & 16.7 & 1 & 40 & 5.4 \\
\hline Rust & AT & 2009 & 21.3 & 82.5 & 46.7 & 2 & 90 & 11.7 \\
\hline Tulln & AT & 2009 & 21.9 & 80.0 & 44.7 & 3 & 90 & 10.5 \\
\hline
\end{tabular}

given. For graphical simplicity no co-segregating markers are shown in Fig. 2. More detailed information on these linkage groups, including all co-segregating markers, their positions and genetic distances are provided in Online Resource 5.

\section{QTL for resistance to stripe rust}

Five versus six field experiments were conducted to evaluate $\mathrm{YrS}$ in population $\mathrm{CA}$ and $\mathrm{CF}$, respectively. Five genomic regions on five chromosomes-2AL, 2BL,
3AS, 3BS, 5A, designated as QYr.ifa-2AL, QYr.ifa-2BL, QYr.ifa-3AS, QYr.ifa-3BS, QYr.ifa-5A-were associated with YrS (Tables 2, 3; Fig. 2). Capo alleles conferred resistances at QYrifa-2AL, QYr.ifa-2BL, QYrifa-3BS and QYr.ifa-5A, and the Arina allele at QYrifa-3AS (Fig. 3). Of these, $Q Y$ r.ifa-2BL and $Q Y$ r.ifa- $3 B S$ were identified in both populations, QYrifa-2AL and QYrifa-3AS in population CA and QYr.ifa-5A in population CF only. Across experiments, by far the greatest effect was contributed by the QTL on 2BL. QYr.ifa-2BL explained between 37 and $58 \%$ of the total phenotypic variance in population 
Theor Appl Genet (2014) 127:2011-2028

2017

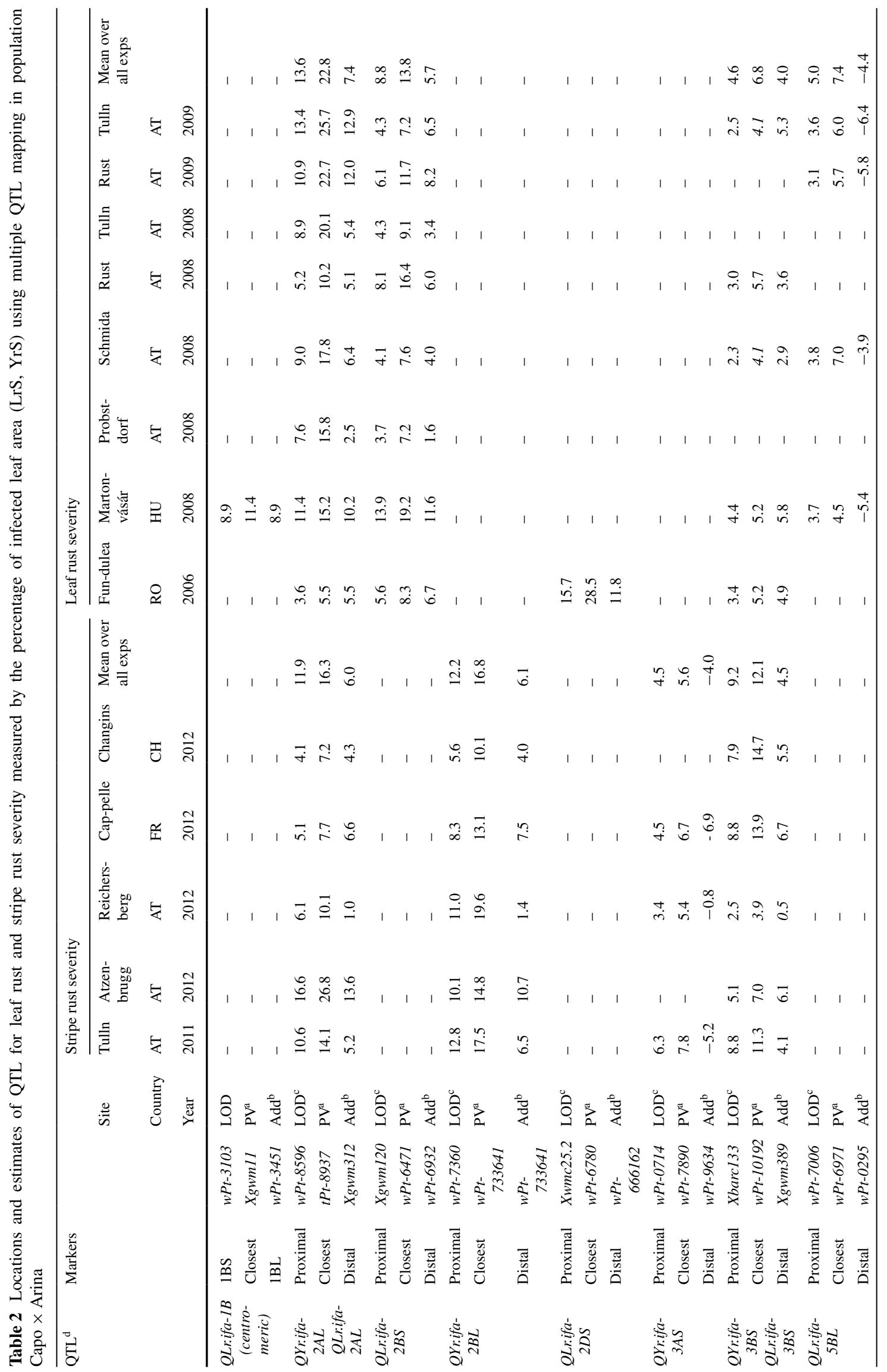

Springer 


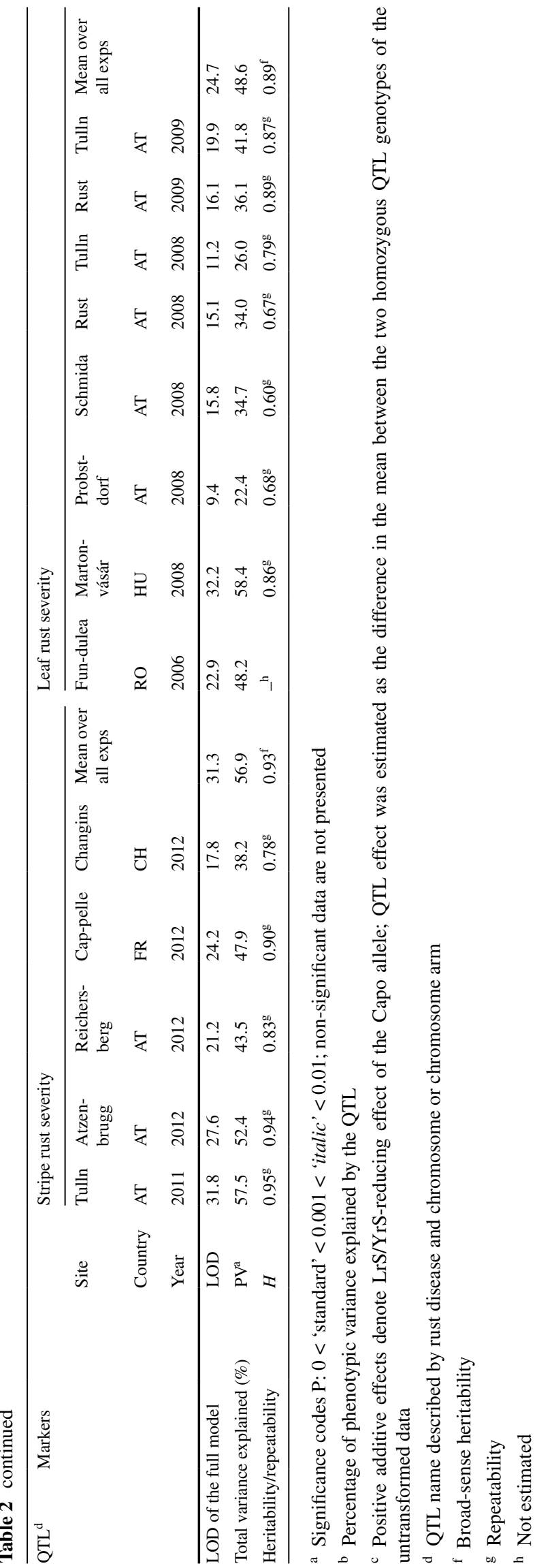

CF (Table 3). Its effect in population CA was less pronounced but still high, contributing $10-20 \%$ to the explained variability (Table 2). QYr.ifa- $2 B L$ is located on the distal end of the long arm and achieved the highest estimates on overlapping intervals at marker wPt-6643 in $\mathrm{CF}$ and at marker wPt-733641 in the CA population. QTL support interval on 3BS spanned over $15 \mathrm{cM}$ and was flanked by Xgwm389 and Xbarc133 in both populations. QYrifa-3BS had a major effect in CF (Table 3), and a moderate effect in population CA (Table 2). QYrifa$2 A L$ was located within a $20 \mathrm{cM}$ interval, with $t P t-8937$ as peak marker. It was an important source of resistance in all experiments of population CA accounting for 7 up to $27 \%$ of the observed variation (Table 2). The corresponding interval on $2 \mathrm{AL}$ was not segregating and thus not observable in population CF. A QTL on chromosome 5A contributed to stripe rust development in four of six experiments in population $\mathrm{CF}$ only. The confidence interval spans a distance of $20 \mathrm{cM}$ and is flanked by Xbarc 117 on the short arm and $w P t-2426$ on the long arm of chromosome 5A. The influence of QYrifa-5A was more variable, with a notable strong effect in one experiment $(20 \%$ $\mathrm{PV})$, but had rather small effects in the other experiments (1.6-5 PV \%) (Table 3). A minor QTL, with resistance contributed by the Arina allele, was identified on the short arm of chromosome $3 \mathrm{~A}$ in three of the five experiments of population CA (Table 2). QTL predominantly acted in an additive manner, although significant epistatic QTL interactions were found in two experiments of population CF (Tulln 2010, Tulln 2011) between QYr.ifa-2BL and QYrifa-3BS. Either of these QTL alone substantially improved resistance (Table 3; Fig. 4). When occurring together, resistance improved slightly relative to the single QTL effect in cases where both favorable alleles were combined, but decreased heavily when both were absent (Fig. 4). Significant interaction between QYrifa- $2 B L$ and QYr.ifa-3BS were additionally found in experiment Reicherberg 2010 and Changings 2010 when using the untransformed dataset (results not shown). No QTL by QTL interactions were found in population CA.

QTL information, particularly allele status at QYrifa$2 B L$ and $Q Y$ r.ifa- $3 B S$ for populations $\mathrm{CF}$, and allele status of at QYrifa-2AL, QYr.ifa-2BL, QYr.ifa-3AL and QYr.ifa$3 B S$ for population $C A$, were used to study the effects of stripe rust QTL in the United Kingdom, an environment with known high pressure of stripe rust (Online Resource 6). Results of population CF clearly separated groups of lines with none, one or two stripe rust resistance QTL alleles, reaching 56, 29, and $14 \% \mathrm{YrS}$, respectively. More QTL were involved in resistance in population CA. Here lines with no QTL were significantly more diseased than all other QTL groups. Lines harboring one or two resistance improving QTL alleles were more resistant 


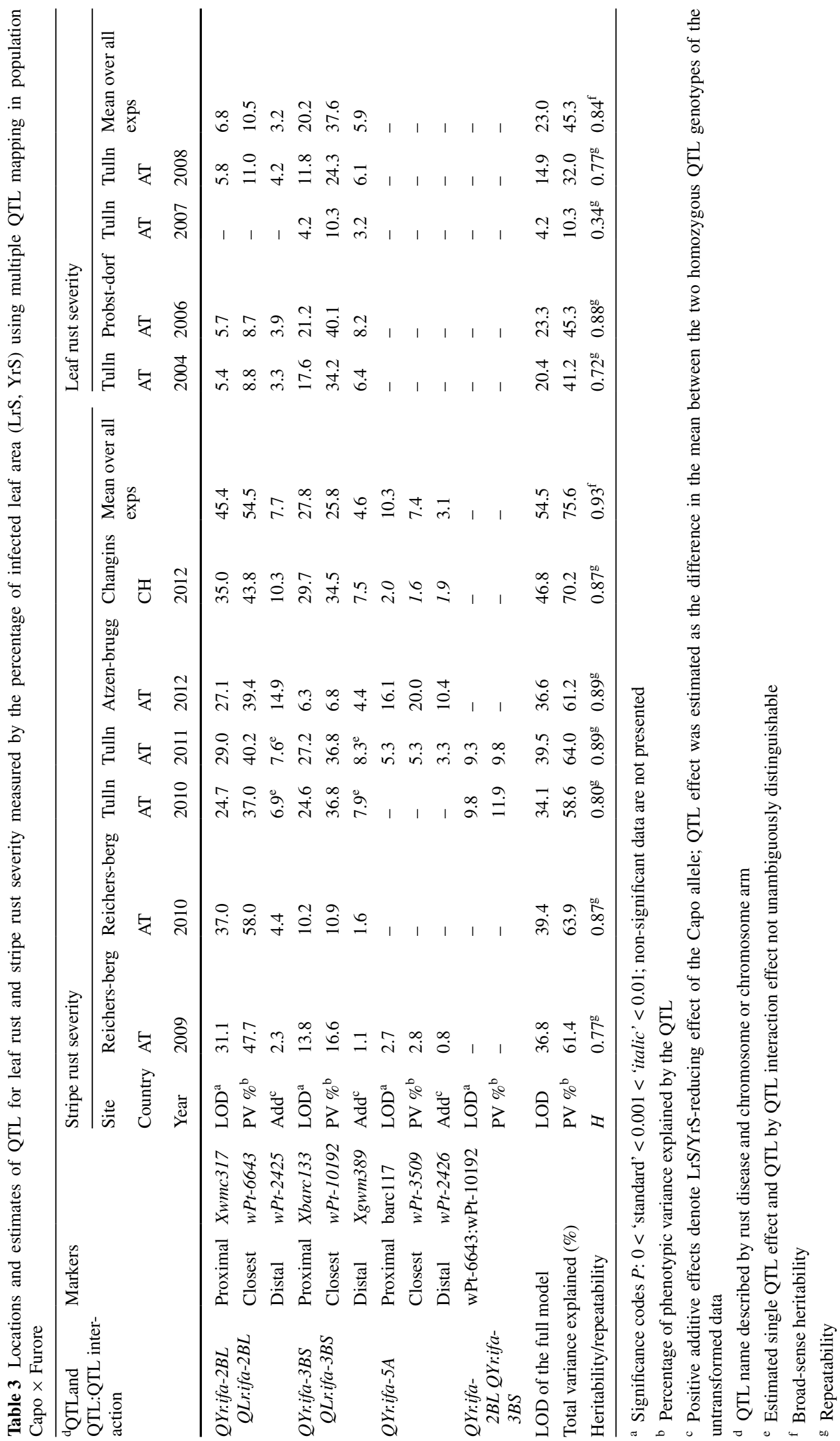



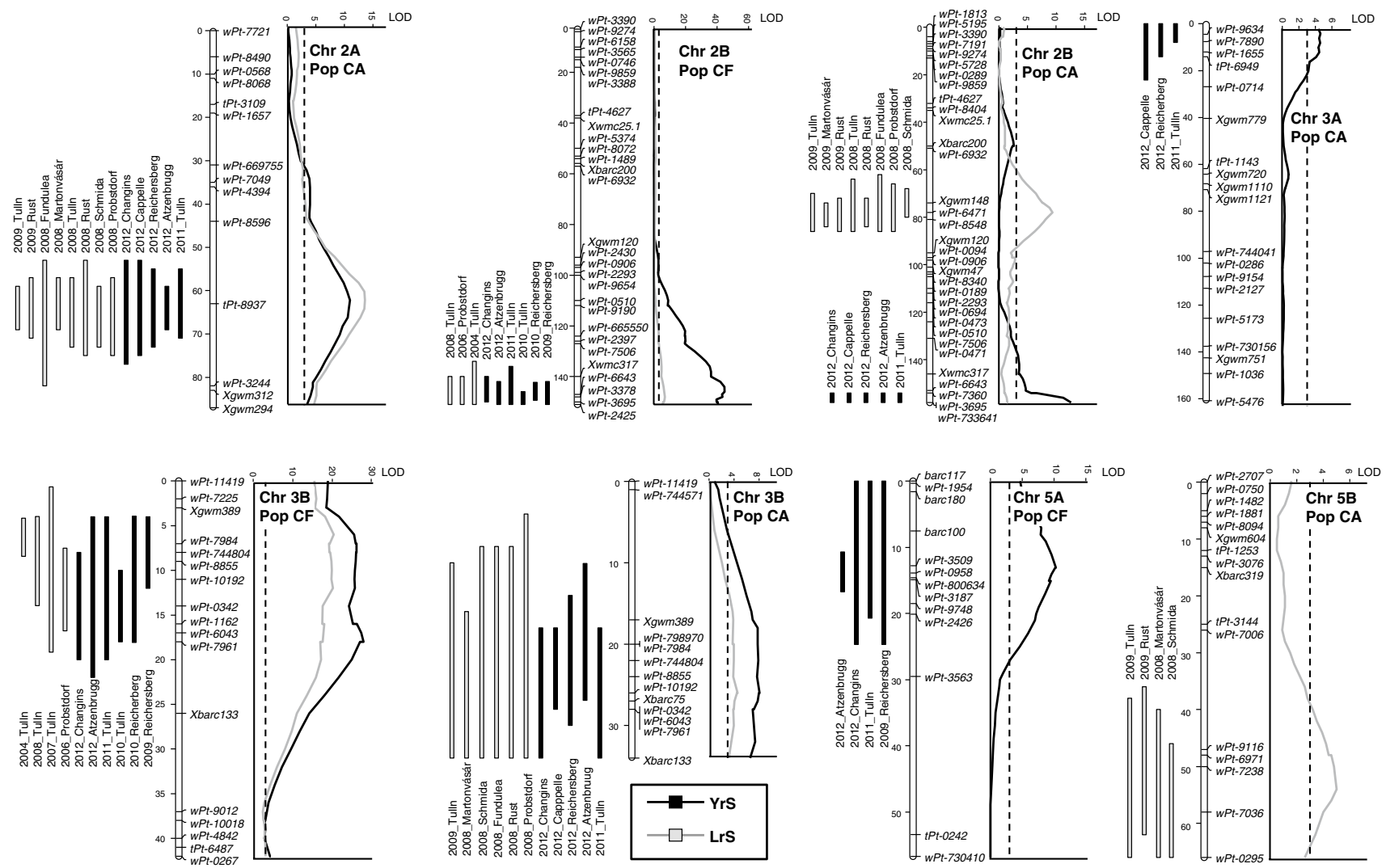

Fig. 2 Maps of linkage groups harbouring QTL identified in multiple experiments. QTL for stipe rust severity (YrS) and leaf rust severity (LrS) are determined by the MQM model. LOD profiles obtained from the averaged mean of all experiments are given on the right.
Bars of the QTL support interval for the respective experiments are on the left. Bar size indicates a LOD decrease of 1.5 from maximum LOD. The dashed lines represent the LOD 3 value

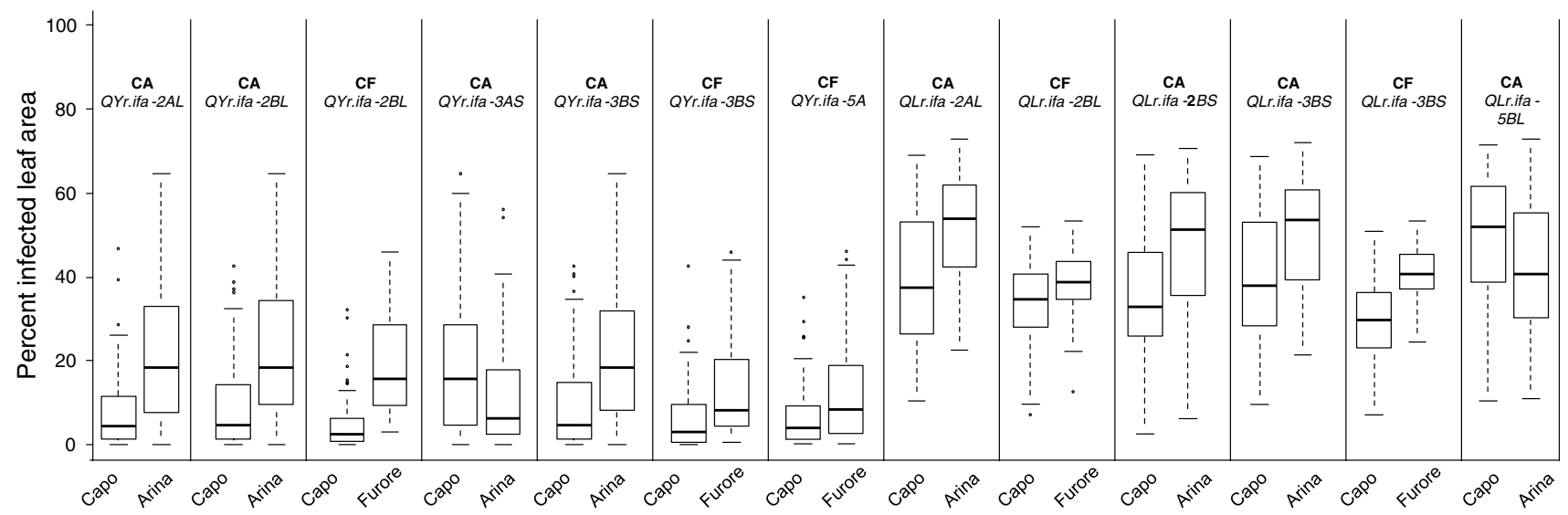

Fig. 3 Boxplot of QTL effects for QTL identified in multiple experiments. Genotypes were classified by allele status of the closest markers to the corresponding QTL. Percentage of infected leaf area of

than lines with no positive allele. The group of lines with four, three or two positive alleles was significantly less infected than lines with one or no stripe rust resistance QTL. stripe rust (YrS) and leaf rust ( $\mathrm{LrS}$ ) are based on average mean values across experiments. Medians are indicated by solid lines

QTL for resistance to leaf rust

LrS was tested in eight respective four experiments of population CA and CF. QTL analysis resulted in five QTL 
Fig. 4 Two-way interaction plots between $Q Y$ rifa- $2 B L$ and QYr.ifa-3BS for each genotypic allele combination of Capo (C) and Furore (F). The phenotypic means are plotted, with error bars at $\pm 1 \mathrm{SE}$
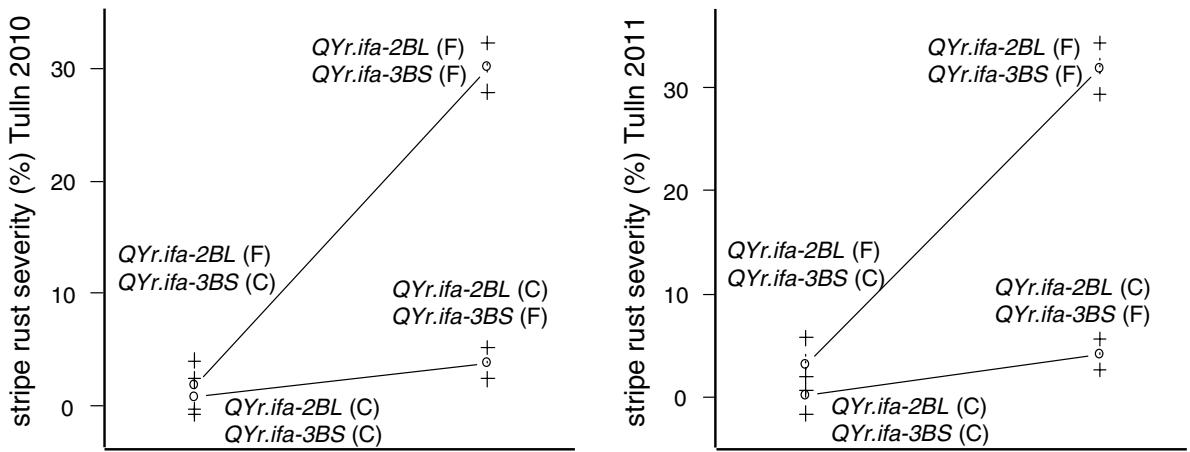

assigned to chromosome arms 2AL, 2BL, 2BS, 3BS and 5BL (QLr.ifa-2AL, QLr.ifa-2BL, QLr.ifa-2BS, QLr.ifa$3 B S$, QLr.ifa-5BL), which were found in multiple experiments (Tables 2, 3; Figs. 2, 3). Besides these repeatedly detected QTL, two further QTL, allocated to chromosomes $1 \mathrm{~B}$ and 2DS (QLr.ifa-1B, QLr.ifa-2DS) were identified in single experiments only. QTL profiles of $Q L$ r.ifa- $1 B$ and QLr.ifa-2DS and boxplots illustrating effects of contrasting alleles are presented in Online Resource 7. Most notably, QLr.ifa-2AL, QLr.ifa-2BL and QLr.ifa-3BS coincided with QTL for YrS. QLrifa-3BS was found in both populations on matching intervals, whereas QLrifa-1B, QLrifa-2AL, QLr.ifa-2BS, QLr.ifa-2DS and QLr.ifa-5BL appeared only in population CA, and QTL on QLr.ifa-2BL was unique for population $\mathrm{CF}$. The Capo allele improved resistance except for QLr.ifa-5BL. Leaf rust resistance in the population $\mathrm{CF}$ was predominantly controlled by the QTL on 3BS which explained 10-34\% of the phenotypic variance (Table 3). QLr.ifa-3BS was less effective in population CA and accounted for 4-6 PV \% in five out of eight experiments (Table 2). QLrifa-2BL was revealed in three of the four CF experiments and showed moderate effects. This QTL coincided with QYr.ifa-2BL, a major source of resistance in the stripe rust experiments (Table 3). QLr.ifa-2AL and QLrifa-2BS were consistently identified in experiments of all years and locations in the population CA and explained on average 23 and $14 \%$ of the phenotypic variance, respectively (Table 2). QLr.ifa-2BS spanned a $15 \mathrm{cM}$ interval and reached maximum values at marker $w P t-647$. The corresponding genomic region of QTL of QLr.ifa- $2 B S$ was not polymorphic over a distance of $30 \mathrm{cM}$ in population $\mathrm{CF}$ (Fig. 2, Online Resource 5). A minor effect QTL on the distal end of chromosome 5BL appeared only in population $\mathrm{CA}$ and was detected in four of the eight experiments. In this case, the susceptible parent Arina conferred the resistance allele (Table 2). Environment specific QTL were identified in the centromeric region of chromosome $1 \mathrm{~B}$ with $X g w m 11$ as peak marker and on the short arm of 2D distal to Xwmc25.2. QLr.ifa-2DS was a major source of resistance in the experiment Fundulea in 2008 and explained $28 \%$ of the phenotypic variance. QLrifa- $1 B$ contributed $11 \%$ of the explained variability in the experiment Martonvásár in 2008 (Table 2, Online Resource 7).

When comparing the results of the two populations the following can be summarized: Capo allele contributed the resistance allele for most QTL, Arina for two QTL, while Furore did not contribute any resistance allele. Three QTL, namely QYr.ifa-2BL, QYrifa-3BS and QLr.ifa-3BS were identified in both populations. Two QTL with resistance conferred by the Capo allele were identified in population CF only (QLr.ifa-2BL, QYr.ifa-5A). Seven QTL were identified in population CA only. In these cases either the genomic intervals were not polymorphic in population $\mathrm{CF}$ (QYr.ifa-2AL, QLr.ifa-2AL, QLr.ifa-2BS), population CF was not tested at the specific environments (QLr.ifa-.2DS, $Q L$ rifa-1B), or the resistance was conferred by the Arina allele (QLr.ifa-5BL, QYr.ifa-3AS).

\section{Discussion}

Capo combines high resistance to stripe rust with moderate resistance to leaf rust and has maintained good resistance levels since its release in 1989 despite extensive cultivation. The reportedly high level of resistance to stripe rust and moderate level to leaf rust was validated in the present study. The key growing area of Capo is conducive to leaf rust, whereas stripe rust occurs only sporadically. Leaf rust symptoms did not show an immune reaction, but a typical quantitative type of resistance. In contrast to Capo's long lasting partial resistance to leaf rust, it remains to be shown whether the exhibited stripe rust resistance will persist over time. So far, Capo sustains its high resistance to stripe rust even under the severe stripe rust epidemic in spring 2014, with the aggressive Warrior race as the dominant pathotype across Europe. Previous multi-pathotype screenings provided evidence, that Capo carries uncharacterized resistances for leaf rust and stripe rust in addition to the resistance genes Lr13 and Yr27 (Winzeler et al. 2000; Pathan and Park 2006; Pathan et al. 2008). Accordingly, our study confirmed the presence of several QTL for resistance to leaf rust and stripe rust in Capo. Frequency distribution of RILs 
for leaf rust severity appeared continuous, suggesting a polygenic and complex genetic control. Indeed, altogether seven different chromosomal regions were associated with LrS, although not all QTL were consistently identified across populations and environments. It is likely that the durable resistance to leaf rust arises from a combination of several low to moderate effect QTL. The rust pathogen can easily adapt its genotype by mutation when facing a single-gene resistance, but is much less likely to overcome several resistance genes in combination (Hovmøller 2001). Frequency distribution of RILs for YrS was continuous but skewed towards low infection and was regulated by five different QTL. The highly significant phenotypic correlations between $\mathrm{LrS}$ and YrS in both populations suggest that resistances to these diseases probably are under some common genetic control. As expected, several coinciding QTL for leaf rust and stripe rust resistance were found. Subpopulations of CA and CF were tested in the United Kingdom to verify if the identified QTL are effective in an environment highly conducive to stripe rust epidemics. The results confirmed that the detected stripe rust resistance QTL confers quantitative resistance also on the United Kingdom.

Multiple-disease-resistance QTL effective for leaf rust and stripe rust

Genotypes possessing multiple-disease-resistance QTL, either closely linked in coupling phase or the pleiotropic effect of a single gene, are particularly valuable in breeding, as these resistances will be inherited simultaneously. QTL mapping identified genomic regions on chromosomes 2AL, 2BL and 3BS which were associated with both $\mathrm{LrS}$ and $\mathrm{YrS}$ and it was always the Capo allele which improved resistance. Wheat homoeologous group 2 chromosomes are a rich source of resistance to both, stripe rust and leaf rust. From the currently designated $\mathrm{Lr}$ and $\mathrm{Yr}$ genes 18 and 12 , respectively have been mapped to group 2 (McIntosh et al. 2012). Homoeologous group 2 was an important source of resistance in the analyzed mapping populations as well, since QTL were detected on all group 2 chromosomes. QTL for $\mathrm{LrS}$ and $\mathrm{YrS}$ co-located to identical intervals on 2AL and were consistently observed in all experiments. Due to lack of polymorphism in population CF at the respective QTL interval, this QTL was only identified in population CA. Resistance genes $\mathrm{Yrl}$ (Macer 1966) and Yr32 (Eriksen et al. 2004) are assigned to chromosome 2AL. Paillard et al. (2012) reported a minor QTL, which marginally overlapped with the QTL interval identified in our study. Resistance was derived from the cultivar Taldor; and there is evidence, that this QTL is race-specific as it was efficient against one single pathotype only. The experiments of the present study were inoculated with different pathotypes or mixtures thereof (Online Resource 2) and the identified resistance QTL was effective against all applied $\mathrm{Yr}$ pathotypes. Capo is susceptible to pathotypes virulent against Yrl and Yr32 (Pathan et al. 2008), thus the detected QTL may be novel. Lr38, a resistance derived from Thinopyrum intermedium (McCallum et al. 2012) and LrTt1, resistances derived from $T$. timopheevii (Leonova et al. 2010) have been up to now the only leaf rust resistance genes reported on the long arm of the $2 \mathrm{~A}$ chromosome. The resistance donor Capo does not contain these translocations, therefore the 2A QTL identified in the current study is likely to be a novel resistance locus for both stripe and leaf rust.

By far the largest contribution to YrS was obtained from QYrifa-2BL. It was detected in all experiments of population $\mathrm{CA}$ and $\mathrm{CF}$ and had a remarkably strong effect in population CF (Tables 2, 3; Fig. 2). Besides its strong contribution to stripe rust resistance, a minor effect for LrS colocated in population CF (Table 3; Fig. 2). Markers linked with resistance mapped on the long arm of the $2 \mathrm{~B}$ chromosome $10 \mathrm{cM}$ distal to Xgwm317. Ordering of DArT markers involved in resistance is in agreement with maps of Mantovani et al. (2008); Francki et al. (2009); Crossa et al. (2007) placing the markers to the distal end of chromosome 2BL, but the relevant markers are more proximal in the consensus map of Marone et al. (2012). Association analysis of CIMMYT elite spring wheat revealed association for both, stripe rust and leaf rust, with DArT markers wPt-3378 and wPt-7360 (Crossa et al. 2007). These markers are located within the confidence interval of QYr.ifa-2BL/QLrifa-2BL. While there is up to now no designated $Y r$ gene reported at the distal end of 2BL, there are two $L r$ genes, $L r 50$ and $\operatorname{Lr} 58$, both derived from alien sources, assigned to the terminal end of 2BL. $L r 50$ is a resistance transferred to wheat from T. timopheevii subsp. armeniacum (Brown-Guedira et al. 2003) and Lr58 is derived from Aegilops triuncialis (Kuraparthy et al. 2007). Neither of these resistances had been deployed in any cultivar when Capo was developed (Brown-Guedira et al. 2003).

QTL for stripe rust and leaf rust co-located on chromosome 3BS and mapped between Xgwm389 and Xbarc133. This interval was consistently associated with YrS in all experiments of both populations and consistent for $\mathrm{LrS}$ in population $\mathrm{CF}$, but it was less effective to $\mathrm{LrS}$ in population CA. This genomic region influences development of many different fungal diseases and has been repeatedly reported in mapping studies of stripe rust, leaf rust, stem rust, powdery mildew and Fusarium head blight. For example, leaf rust gene Lr27 (Nelson et al. 1997), stem rust gene $\mathrm{Sr} 2$ (Spielmeyer et al. 2003; Kota et al. 2006), stripe rust gene Yr30 (Singh et al. 2001), YrRub (Bansal et al. 2010), powdery mildew (Mago et al. 2011) and Fusarium head blight gene Fhbl (Liu et al. 2008) are located in this interval. Tight linkage exists between partial APR gene $S r 2$, seedling 
resistance gene $L r 27$, partial APR gene $Y r 30$, pseudo-black chaff (PBC) (Singh and McIntosh 1984) and powdery mildew (Mago et al. 2011). PBC causes a genotype-dependent pigmentation of stems and/or glumes and has long been used as a phenotypic marker for $\operatorname{Sr} 2$ (McFadden1939; Hare and McIntosh 1979). Mago et al. (2011) hypothesize, that a single gene on chromosome arm 3BS may be responsible for resistance to these three fungal pathogens. Capo, the resistance donor on 3BS, does neither contain leaf rust gene $L r 27$ (Park et al. 2001) nor stem rust gene $S r 2$ (Pathan 2007) and does not develop PBC. Hence QLrifa-3BS and QYr.ifa-3BS identified in our study appear to be distinct to the above multiple-disease-resistance genes. The resistance gene $Y r R u b$, which is likely identical to $Y r 4$, was mapped on 3BS close to Xgwm75 (Bansal et al. 2010). Multi-pathotype screening for stripe rust did not detect $\mathrm{Yr} 4$ in Capo (Pathan et al. 2008). Furthermore, all pathotype populations used for inoculation were virulent to $\mathrm{Yr} 4$ (Online Resource 2). The identified QYrifa-3BS therefore differs from $Y r 4$. Stripe rust QTL have been repeatedly identified in this region (Boerner et al. 2000; Singh et al. 2000b; 2001; Suenaga et al. 2003; William et al. 2006; Khlestkina et al.2007; Dedryver et al. 2009; Lowe et al. 2011b; Hao et al. 2011). Ingala et al. (2012) identified gene LrSV2, which coincides with $L r 27$, but unlike the seedling gene $L r 27, L r S V 2$ is effective at adult plant stage only. Additional studies are necessary to precisely locate the QTL on $3 \mathrm{BS}$, to elucidate the relationship to other resistance genes and to investigate if $Q L$ rifa- $3 B S$ and $Q Y$ r.ifa- $3 B S$ are closely linked or a single pleiotropic gene. Potentially, all three identified multiple-disease-resistance QTL contribute novel resistance sources for stripe rust and leaf rust.

Studies for epistatic interaction provide additional information on desirable and undesirable combinations of genes. The present study revealed epistatic additive $\mathrm{x}$ additive interaction for QYrifa- $2 B L$ and $Q Y$ rifa- $3 B S$ in two experiments of population CF. In this particular case, the presence of one favorable allele neutralized much of the effect of the other favorable allele. Similarly, Yang et al. (2013) observed, that combinations of specific $Y r$ genes, when occurring together, had the same disease severity as lines containing either of the loci alone and Lowe et al. (2011b) found, that individual effects of QTL, when combined, were greater in the absence of resistant alleles from the other. In wheat lines with combinations of major resistance genes, usually the gene with greatest resistant infection type is epistatic to genes with less resistant infection types (Bolton 2008). However, our results indicate that pyramiding of these QTL will improve overall resistance. The effect of $Q Y$ rifa-2BL varied from moderate to major, whereas effect of QYrifa-3BS was minor to moderate. This suggests that $Q Y$ rifa- $2 B L$ is a major and putatively racespecific resistance gene, while $Q Y$ r.ifa- $3 B S$ may or may not be race-specific. The identification of a major gene for YrS verified the finding of Pathan et al. (2008), that Capo carries an uncharacterized seedling resistance gene in addition to $\operatorname{Yr} 27$.

\section{QTL effective for resistance to leaf rust only}

The QLrifa-2BS was found in population CA only. It mapped close to the centromere near Xgwml48 (Fig. 2). The corresponding chromosomal region was not polymorphic in population CF, accordingly no QTL was detected. Lr13, Lr16, Lr23, Lr35, Lr48 all appear to be close to Xgwm148 (Maccaferri et al. 2010) near to the centromere and overlapping with QLrifa-2BS. Lr13 (Bansal et al. 2008), Lr16 (McCartney et al. 2005), Lr23 (Nelson et al.1997), Lr35 (Seyfarth et al. 1999) are located on 2BS, while $L r 48$ has been reported on both the short arm (Bansal et al. 2008) and on the long arm of chromosome 2B (Singh et al. 2011b). Lrl3 has been one of the most widely distributed resistance genes worldwide (McIntosh et al. 1995); in contrast, Lr35 had not been used in modern cultivars when Capo was released. A screening survey of European winter wheat germplasm for $L r$ genes confirmed the presence of Lrl3 and the absence of Lrl6 and Lr23 in both, Capo and Arina (Winzeler et al. 2000; Park et al. 2001). Presumably Furore also carries $\operatorname{Lr} 13$, because the corresponding genomic region was monomorphic between Capo and Furore. It is therefore likely that both mapping populations are fixed for $\mathrm{Lr} 13$. In addition virulence to $\mathrm{Lr} 13$ appears widespread in Europe (Mesterhazy et al. 2000) and was with high probability present in our leaf rust populations. Whether or not $\mathrm{Lr} 13$ had a modulating effect on the leaf rust resistance QTL detected in this study remains unknown. Several QTL studies (Messmer et al. 2000; Xu et al. 2005a, b; Leonova et al. 2007; Rosewarne et al. 2008; Prins et al. 2011) detected QTL of various leaf rust related traits at a similar location. This repeated finding highlights the importance of the centromeric region of $2 \mathrm{BS}$ for leaf rust resistance. Whether or not QLrifa-2BS corresponds to any of these previously reported genes or QTL is not yet clarified. In the current study, a QTL for LrS near the telomere of 2DS was detected in the experiment conducted in Romania only. Interestingly, while all other QTL identified in this study were also significant, the 2DS QTL had the most enhanced effect in this particular environment. Mesterhazy et al. (2000) conducted a virulence survey of the wheat leaf rust pathogen in Europe and verified a great diversity in the European population of the wheat leaf rust fungus. As individual leaf rust experiments were inoculated with a mixture of pathotypes collected in surrounding areas of the experimental sites, the used pathogen populations may differ in their virulence profiles. This would suggest that Capo has a race specific response at this interval. 
Several leaf rust genes are assigned to 2DS of which $\operatorname{Lr} 15$, $L r 22$ (alleles $L r 22 a, L r 22 b$ ) and $L r 39$ have been mapped to telomeric regions of chromosome 2DS (Dholakia et al. 2013; Hiebert et al. 2007; Raupp et al. 2001), whereas $L r 2$ (alleles $L r 2 a, L r 2 b, L r 2 c$ ) is more proximal (McIntosh et al. 1995). Capo does not carry $L r 2 a, L r 2 c$ and $L r 15$ (Winzeler et al. 2000; Park et al. 2001). Lr39 and Lr22a were introgressed from T. tauschii (Raupp et al. 2001; Rowland and Kerber 1974) and Lr15 and Lr22b originate from T. aestivum and were first described in Kenya W1483 (Luig and McIntosh 1968) and in the old Canadian cultivar Marquis (Bartos et al. 1969), respectively. Considering the pedigree of Capo, it is unlikely that the detected QTL is equivalent to $L r 22 a$ or $L r 39$ but the pedigree of Capo includes Marquis (Martynov et al. 2006), therefore Capo potentially contains $L r 22 b$. Further studies are necessary to clarify whether or not the resistance QTL on 2DS corresponds to Lr22b. QLrifa- $1 B$ was only observed in the experiment conducted in Hungary. The flanking markers $w P t-3103$ and $w P t-3451$ are located on the short and long arm of chromosome 1B respectively (Marone et al. 2012) placing the QTL near the centromere. Currently, there are seven leaf rust resistance genes and two leaf rust QTL assigned to chromosome 1B (McIntosh et al.2012), of which Lr33 (Dyck et al. 1987), Lr44 (Dyck and Sykes 1994), Lr71 (Singh et al. 2013), LrZH84 (Zhao et al. 2008), QLr.ifa-pser.1BL (Li and Bai 2009) and QLr.ifa-sfr-1B (Messmer et al. 2000) are all mapped close to the centromere. Unfortunately, with the present study we cannot conclude if QLrifa- $1 B$ corresponds to any of these genes or QTL. Although QLrifa$2 D S$ and $Q L$ rifa- $I B$ can be useful in certain environments, these QTL should be deployed in combination with other genes, as they may be of little use in regions where the corresponding virulence is present. QLr.ifa- $5 B L$ contributed to leaf rust resistance in two of five experiments in population CA. Markers associated with leaf rust mapped to the distal end of the long arm of chromosome 5B according maps of Marone et al. (2012) and Crossa et al. (2007). So far no leaf rust gene was reported in this interval. However, association studies of wheat landraces identified marker-leaf rust associations at this genomic region (Bansal et al. 2013).

\section{QTL effective for resistance to stripe rust only}

Pathan et al. (2008) evaluated stripe rust resistance of European wheat cultivars and reported high adult plant resistance for Arina, while in our trials Arina was moderately susceptible. QYrifa-3AS was the only QTL with an Arina derived resistance improvement. It had a minor effect and was significant in three of five experiments. Associations between chromosome $3 \mathrm{~A}$ and stripe rust have been reported in a few studies, although no stripe rust gene has been assigned to 3A so far. Lillemo et al. (2008) and Roswarne et al. (2012) identified minor effect QTL, derived from cv. Saar and cv. Avocet, which coincide with QYrifa-3AS in the present study and an association analysis of CIMMYT elite spring wheat germplasm identified several markers associated with stripe rust within the support interval of QYr.ifa-3AS (Crossa et al. 2007). Some common ancestors are involved in the pedigree of Arina compared to the resistance donor Saar and Avocet (http://genbank.vurv.cz/wheat/ pedigree), thus these cultivars potentially share a common resistance allele. A QTL on chromosome 5A influenced stripe rust response in five of eight experiments in population CF. QYrifa-5A mapped in the centromeric region of 5A. It was not possible to unambiguously assign QYrifa$5 A$ to a chromosomal arm, but the QTL clearly resides close to the centromere. Fang et al. (2011) reported a QTL on the centromeric region of the long arm derived from cultivar Jagger and Quan et al. (2013) identified a QTL on the centromeric region of the short arm of chromosome $5 \mathrm{~A}$ derived from a Chinese wheat land race. Both QTL are located within the confidence interval of QYrifa-5A.

\section{Conclusions}

Breeding for rust resistance is a continuous effort. New races regularly overcome race-specific resistance genes and novel resistances need to be integrated into breeding germplasm to maintain a required resistance level. The present study identified seven QTL for leaf rust and five QTL for stripe rust resistance and confirmed Capo as an important source for improving rust resistance. The longlasting resistance of Capo apparently rests upon a combination of several minor and major genes. This finding confirms that the genetic architecture of durable resistant cultivars is complex, usually modulated by a set of genes rather than by a single major gene. QTL on $2 \mathrm{AL}, 2 \mathrm{BL}$ and 3BS were associated with both, leaf rust and stripe rust, either through close linkage or pleiotropy. Deploying such multiple-disease resistances in breeding is particularly advantageous, as they enable improvement of stripe rust and leaf rust resistance simultaneously. The study identified several resistance alleles, but further genetic tests are required to prove, whether the detected QTL correspond to already published genes. But regardless of whether they refer to any previously reported gene or QTL, they are a valuable resistance source embedded in a high quality and successfully deployed cultivar ready for use as a parent in winter wheat breeding. Molecular markers closely linked to the QTL can be used for marker-assisted selection. The identified QTL can help to develop cultivars with multiple-resistance-genes in combination that will hopefully provide a long lasting consistent level of disease resistance. 
Author contributions Buerstmayr M: phenotyping of stripe rust and leaf rust experiments in Austria, SSR markers, map calculation, map validation, QTL analysis, manuscript writing.

Matiasch L: phenotyping of leaf rust experiments in Austria

Mascher F: phenotyping of stripe rust experiments in Switzerland.

Vida G: phenotyping of leaf rust experiments in Hungary.

Ittu M: phenotyping of leaf rust experiments in Romaina.

Robert O: phenotyping of stripe rust experiments in France.

Holdgate S: phenotyping of stripe rust experiments in UK.

Flath K: providing of stripe rust spores.

Neumayer A: phenotyping of stripe rust and leaf rust experiments in Austria.

Buerstmayr H: project leader and project supervisor.

Acknowledgments We gratefully thank Gemma Rose and Nick Gosman, NIAB, Cambridge, UK, for their support with the Yr experiment at Cambridge. Gemma Rose was funded by BB/I002561/1 from the UK Biotechnology and Biological Sciences Research Council. We thank Frank Ordon, JKI, Germany, as well as Valéria Šudyová and Svetlana Šliková, Research Institute of Plant Production, Piešlany, Slovakia, for sowing field trials at their locations, which results were not included in this publication because of too low disease pressure. We acknowledge the excellent technical assistance in the laboratory work by Katrin Herzog and in the field work by Lisa Schmid and Matthias Fidesser.We thank Wolfgang Schweiger for reading and constructive criticism of the manuscript. We acknowledge funding of this research through the Austrian Science Fund (FWF), project number L182-B06.

Conflict of interest The authors declare that they have no conflicts of interest.

Open Access This article is distributed under the terms of the Creative Commons Attribution License which permits any use, distribution, and reproduction in any medium, provided the original author(s) and the source are credited.

\section{References}

Akbari M, Wenzl P, Caig V, Carling J, Xia L, Yang SY, Uszynski G, Mohler V, Lehmensiek A, Kuchel H, Hayden MJ, Howes N, Sharp P, Vaughan P, Rathmell B, Huttner E, Kilian A (2006) Diversity arrays technology (DArT) for high-throughput profiling of the hexaploid wheat genome. Theor Appl Genet 113:1409-1420

BAES (2013) Die in Österreich erzeugten Saatgutmengen der Saison 2012/2013 unter Berücksichtigung der Art und Sorte, gegliedert nach beantragten und zertifizierten Mengen. AGES/BAES-Institut für Saatgut. Tabelle IV/2.3 http://www.baes.gv.at/uploads/ media/Gewichte_2012_2013.pdf. Accessed 7 Mar 2014

Bansal UK, Hayden MJ, Venkata BP, Khanna R, Saini RG, Bariana HS (2008) Genetic mapping of adult plant leaf rust resistance genes $\operatorname{Lr} 48$ and $L r 49$ in common wheat. Theor Appl Genet 117:307-312

Bansal UK, Hayden MJ, Gill MB, Bariana HS (2010) Chromosomal location of an uncharacterised stripe rust resistance gene in wheat. Euphytica 171:121-127

Bansal UK, Arief VN, DeLacy IH, Bariana HS (2013) Exploring wheat landraces for rust resistance using a single marker scan. Euphytica 194:219-233

Bartos P, Dyck PL, Samborski DJ (1969) Adult-plant leaf rust resistance in Thatcher and Marquis wheat, a genetic analysis of the host-parasite interaction. Can J of Botany 47:267-269

Boerner A, Roeder MS, Unger O, Meinel A (2000) The detection and molecular mapping of a major gene for non-specific adult-plant disease resistance against stripe rust (Puccinia striiformis) in wheat. Theor Appl Genet 100:1095-1099

Bolton M, Kolmer J, Garvin D (2008) Wheat leaf rust caused by Puccinia triticina. Mol Plant Pathol 9:563-575

Broman KW, Wu H, Sen S, Churchill GA (2003) R/qtl: qTL mapping in experimental crosses. Bioinformatics 19:889-890

Brown-Guedira GL, Singh S, Fritz AK (2003) Performance and mapping of leaf rust resistance transferred to wheat from Triticum timopheevii subsp armeniacum. Phytopatholy 93:784-789

Chen X (2007) Challenges and solutions for stripe rust control in the United States. Aust J Agric Res 58:648-655

Chu C, Friesen T, Xu S, Faris J, Kolmer J (2009) Identification of novel QTLs for seedling and adult plant leaf rust resistance in a wheat doubled haploid population. Theor Appl Genet 119:263-269

Crossa J, Burgueno J, Dreisigacker S, Vargas M, Herrera-Foessel S, Lillemo M, Singh R, Trethowan R, Warburton M, Franco J, Reynolds M, Crouch J, Ortiz R (2007) Association analysis of historical bread wheat germplasm using additive genetic covariance of relatives and population structure. Genetics 177:1889-1913

de Givry S, Bouchez M, Chabrier P, Milan D, Schiex T (2005) Carthagene:multipopulation integrated genetic and radiation hybrid mapping. Bioinformatics 21:1703-1704

Dedryver F, Paillard S, Mallard S, Robert O, Trottet M, Negre S, Verplancke G, Jahier J (2009) Characterization of genetic components involved in durable resistance to stripe rust in the bread wheat 'Renan'. Phytopatholgy 99:968-973

Development Core Team R (2011) R: a language and environment for statistical computing. R Found statistical comput, Vienna

Dholakia BB, Rajwade AV, Hosmani P, Khan RR, Chavan S, Reddy DMR, Lagu MD, Bansal UK, Saini RG, Gupta VS (2013) Molecular mapping of leaf rust resistance gene Lr15 in hexaploid wheat. Mol Breed 31:743-747

Dyck PL, Sykes EE (1994) Genetics of leaf-rust resistance in three spelt wheats. Can J Plant Sci 74:231-233

Dyck PL, Kerber ER, Lukow OM (1987) Chromosome location and linkage of a new gene (Lr33) for reaction to Puccinia recondita. Genome 29:463-466

Eriksen L, Afshari F, Christiansen M, McIntosh R, Jahoor A, Wellings C (2004) Yr32 for resistance to stripe (yellow) rust present in the wheat cultivar Carstens V. Theor Appl Genet 108:567-575

Fang T, Campbell K, Liu Z, Chen X, Wan A, Li S, Liu Z, Cao S, Chen Y, Bowden R, Carver B, Yan L (2011) Stripe rust resistance in the wheat cultivar jagger is due to $\operatorname{Yr} 17$ and a novel resistance gene. Crop Sci 51:2455-2465

Faris JD, Li WL, Liu DJ, Chen PD, Gill BS (1999) Candidate gene analysis of quantitative disease resistance in wheat. Theor Appl Genet 98:219-225

Flor HH (1956) The complementary gene systems in flax and flax rust. Adv Genet 8:29-54

Francki MG, Walker E, Crawford AC, Broughton S, Ohm HW, Barclay I, Wilson RE, McLean R (2009) Comparison of genetic 
and cytogenetic maps of hexaploid wheat (Triticum aestivum L.) using SSR and DArT markers. Mol Genet Genomics 281:181-191

Haley SC, Knott AS (1992) A simple regression method for mapping quantitative trait loci in line crosses using flanking markers. Heredity 69:315-324

Hao Y, Chen Z, Wang Y, Bland D, Buck J, Brown-Guedira G, Johnson J (2011) Characterization of a major QTL for adult plant resistance to stripe rust in US soft red winter wheat. Theor Appl Genet 123:1401-1411

Hare RA, McIntosh RA (1979) Genetic and cytogenetic studies of durable adult-plant resistances in Hope and related cultivars to wheat rusts. Z Planzenzüchtung 83:350-367

Heath M (2000) In this issue 'Multigenic disease resistance and the basis of host genotype specificity'. Physiol Mol Plant P 57:189-190

Hiebert CW, Thomas JB, Somers DJ, McCallum BD, Fox SL (2007) Microsatellite mapping of adult-plant leaf rust resistance gene Lr22a in wheat. Theor Appl Genet 115:877-884

Hovmøller M (2001) Disease severity and pathotype dynamics of Puccinia striiformis f.sp tritici in Denmark. Plant Pathol 50:181-189

Hovmøller M, Yahyaoui A, Milus E, Justesen A (2008) Rapid global spread of two aggressive strains of a wheat rust fungus. Mol Ecol 17:3818-3826

Ingala L, Lopez M, Darino M, Pergolesi MF, Dieguez MJ, Sacco F (2012) Genetic analysis of leaf rust resistance genes and associated markers in the durable resistant wheat cultivar Sinvalocho MA. Theor Appl Genet 124:1305-1314

Johnson R (1981) Durable resistance, definition of, genetic control, and attainment in plant breeding. Phytopatholgy 71:567-568

Johnson R (1992) Reflections of a plant pathologist on breeding for disease resistance, with emphasis on yellow rust and eyespot of wheat. Plant Pathol 41:239-254

Khlestkina EK, Roder MS, Unger O, Meinel A, Borner A (2007) More precise map position and origin of a durable non-specific adult plant disease resistance against stripe rust (Puccinia striiformis) in wheat. Euphytica 153:1-10

Kolmer JA, Mert Z, Akan K, Demir L, Unsal R, Sermet C, Keser M, Akin B, Morgounov A (2013) Virulence of Puccinia triticina in Turkey and leaf rust resistance in Turkish wheat cultivars. Eur J Plant Pathol 135:703-716

Kota R, Spielmeyer W, McIntosh RA, Lagudah ES (2006) Fine genetic mapping fails to dissociate durable stem rust resistance gene $\mathrm{Sr} 2$ from pseudo-black chaff in common wheat (Triticum aestivum L.). Theor Appl Genet 112:492-499

Krattinger S, Lagudah E, Spielmeyer W, Singh R, Huerta-Espino J, McFadden H, Bossolini E, Selter L, Keller B (2009) A putative $\mathrm{ABC}$ transporter confers durable resistance to multiple fungal pathogens in wheat. Science 323:1360-1363

Kuraparthy V, Sood S, Chhuneja P, Dhaliwal HS, Kaur S, Bowden RL, Gill BS (2007) A cryptic wheat-Aegilops triuncialis translocation with leaf rust resistance gene Lr58. Crop Sci 47:1995-2003

Lagudah ES, Krattinger SG, Herrera-Foessel S, Singh RP, HuertaEspino J, Spielmeyer W, Brown-Guedira G, Selter LL, Keller B (2009) Gene-specific markers for the wheat gene Lr34/Yr18/ Pm38 which confers resistance to multiple fungal pathogens. Theor Appl Genet 119:889-898

Leonova IN, Laikova LI, Popova OM, Unger O, Borner A, Roder MS (2007) Detection of quantitative trait loci for leaf rust resistance in wheat-T-timopheevii/T-tauschii introgression lines. Euphytica 155:79-86

Leonova IN, Budashkina EB, Flath K, Weidner A, Borner A, Roder MS (2010) Microsatellite mapping of a leaf rust resistance gene transferred to common wheat from Triticum timopheevii. Cereal Res Commun 38:211-219
Li T, Bai GH (2009) Lesion mimic associates with adult plant resistance to leaf rust infection in wheat. Theor Appl Genet 119: $13-21$

Lillemo M, Asalf B, Singh R, Huerta-Espino J, Chen X, He Z, Bjornstad A (2008) The adult plant rust resistance loci $\operatorname{Lr} 34 / Y r 18$ and Lr46/Yr29 are important determinants of partial resistance to powdery mildew in bread wheat line Saar. Theor Appl Genet 116:1155-1166

Lin F, Chen X (2007) Genetics and molecular mapping of genes for race-specific all-stage resistance and non-race-specific hightemperature adult-plant resistance to stripe rust in spring wheat cultivar Alpowa. Theor Appl Genet 114:1277-1287

Liu SX, Pumphrey MO, Gill BS, Trick HN, Zhang JX, Dolezel J, Chalhoub B, Anderson JA (2008) Toward positional cloning of Fhb1, a major QTL for Fusarium head blight resistance in wheat. Cereal Res Commun 36:195-201

Lowe I, Cantu D, Dubcovsky J (2011a) Durable resistance to the wheat rusts: integrating systems biology and traditional phenotype-based research methods to guide the deployment of resistance genes. Euphytica 179:69-79

Lowe I, Jankuloski L, Chao S, Chen X, See D, Dubcovsky J (2011b) Mapping and validation of QTL which confer partial resistance to broadly virulent post-2000 North American races of stripe rust in hexaploid wheat. Theor Appl Genet 123:143-157

Luig NH, McIntosh RA (1968) Location and linkage of genes on wheat chromosome 2D. Can J Genet Cytol 10:99-105

Maccaferri M, Mantovani P, Tuberosa R, DeAmbrogio E, Giuliani S, Demontis A, Massi A, Sanguineti MC (2008) A major QTL for durable leaf rust resistance widely exploited in durum wheat breeding programs maps on the distal region of chromosome arm 7BL. Theor Appl Genet 117:1225-1240

Maccaferri M, Sanguineti MC, Mantovani P, Demontis A, Massi A, Ammar K, Kolmer JA, Czembor JH, Ezrati S, Tuberosa R (2010) Association mapping of leaf rust response in durum wheat. Mol Breed 26:189-228

Macer RCF (1966) The formal and monosomic genetic analysis of stripe rust (Puccinia striiformis) resistance in wheat. In: MacKey J (ed) Proceedings of 2nd international wheat genetics symposium, Lund. Hereditas Suppl 2, pp 127-142

Mago R, Tabe L, McIntosh RA, Pretorius Z, Kota R, Paux E, Wicker T, Breen J, Lagudah ES, Ellis JG, Spielmeyer W (2011) A multiple resistance locus on chromosome arm 3BS in wheat confers resistance to stem rust ( $\mathrm{Sr} 2)$, leaf rust ( $\mathrm{Lr} 27)$ and powdery mildew. Theor Appl Genet 123:615-623

Mantovani P, Maccaferri M, Sanguineti MC, Tuberosa R, Catizone I, Wenzl P, Thomson B, Carling J, Huttner E, DeAmbrogio E, Kilian A (2008) An integrated DArT-SSR linkage map of durum wheat. Mol Breed 22:629-648

Marone D, Laido G, Gadaleta A, Colasuonno P, Ficco DBM, Giancaspro A, Giove S, Panio G, Russo MA, De Vita P, Cattivelli L, Papa R, Blanco A, Mastrangelo AM (2012) A high-density consensus map of A and B wheat genomes. Theor Appl Genet 125:1619-1638

Martynov SP, Dobrotvorskaya TV, Hon I, Faberova I (2006) WheatPedigree and identified alleles of genes-on line. N.I. Vavilov Institute of Plant Industry, St. Petersburg and Crop Research Institute, Praha http://genbank.vurv.cz/wheat/pedigree/default.htm. Accessed 7 Mar 2014

McCallum BD, Hiebert CW, Huerta-Espino J, Cloutier S (2012) Wheat leaf rust. In: Sharma I (ed) Disease resistance in wheat. CABI plant protection series 1 , Wallingford, CABI, pp $33-62$

McCartney CA, Somers DJ, McCallum BD, Thomas JG, Humphreys DG, Menzies JG, Brown PD (2005) Microsatellite tagging of the leaf rust resistance gene $\operatorname{Lr} 16$ on wheat chromosome 2BSc. Mol Breed 15:329-337 
McFadden ES (1939) Brown necrosis, a discoloration associated with rust infection in certain rust-resistant wheats. J Agri Res 58:0805-0819

McIntosh RA (1992) Close genetic linkage of genes conferring adult plant resistance to leaf rust and stripe rust in wheat. Plant Pathol 41:523-527

McIntosh RA, Wellings CR, Park RF (1995) Wheat rusts: an atlas of resistance genes. CSIRO Publications, East Melbourne, pp $10-22$

McIntosh RA, Yamazaki Y, Dubcovsky J, Rogers J, Morris C, Somers DJ, Appels R, Devos KM (2012) Catalogue of gene symbols for wheat. http://www.shigen.nig.ac.jp/wheat/komugi/genes/ download.jsp. Accessed 7 Mar 2014

Messmer MM, Seyfarth R, Keller M, Schachermayr G, Winzeler M, Zanetti S, Feuillet C, Keller B (2000) Genetic analysis of durable leaf rust resistance in winter wheat. Theor Appl Genet 100:419-431

Mesterhazy A, Bartos P, Goyeau H, Niks RE, Csosz M, Andersen O, Casulli F, Ittu M, Jones E, Manisterski J, Manninger K, Pasquini M, Rubiales D, Schachermayr G, Strzembicka A, Szunics L, Todorova M, Unger O, Vanco B, Vida G (2000) European virulence survey for leaf rust in wheat. Agronomie 20:793-804

Milus E, Kristensen K, Hovmoller M (2009) Evidence for increased aggressiveness in a recent widespread strain of Puccinia striiformis f. sp tritici causing stripe rust of wheat. Phytopatholgy 99:89-94

Moll E, Walther U, Flath K, Prochnow J, Sachs E (1996) Methodische Anleitung zur Bewertung der partiellen Resistenz und die SAS-Anwendung RESI. Berichte aus der Biologischen Bundesanstalt für Land- und Forstwirtschaft, Heft 12. Saphir Verlag, Ribbesbüttel, DE

Navabi A, Tewari J, Singh R, McCallum B, Laroche A, Briggs K (2005) Inheritance and QTL analysis of durable resistance to stripe and leaf rusts in an Australian cultivar, Triticum aestivum 'Cook'. Genome 48:97-107

Nelson JC, Singh RP, Autrique JE, Sorrells ME (1997) Mapping genes conferring and suppressing leaf rust resistance in wheat. Crop Sci 37:1928-1935

Nyquist WE (1991) Estimation of heritability and prediction of selection response in plant populations. Crit Rev Plant Sci 10:235-322

Ohm HW, Shaner GE (1976) 3 components of slow leaf-rusting at different growth stages in wheat. Phytopatholgy 66:1356-1360

Paillard S, Trotoux-Verplancke G, Perretant M, Mohamadi F, Leconte M, Coedel S, de Vallavieille-Pope C, Dedryver F (2012) Durable resistance to stripe rust is due to three specific resistance genes in French bread wheat cultivar Apache. Theor Appl Genet 125:955-965

Park R, Goyeau H, Felsenstein F, Bartos P, Zeller F (2001) Regional phenotypic diversity of Puccinia triticina and wheat host resistance in Western Europe, 1995. Euphytica 122:113-127

Parlevliet JE (1985) Resistance of the nonrace-specific type. In: Roelfs AP, Bushnell WR (eds) The Cereal Rust II. Academic Press, New York, pp 501-525

Pathan A, Park R (2006) Evaluation of seedling and adult plant resistance to leaf rust in European wheat cultivars. Euphytica 149:327-342

Pathan AK, Park RF (2007) Evaluation of seedling and adult plant resistance to stem rust in European wheat cultivars. Euphytica 155:87-105

Pathan A, Wellings C, Bariana H, Park R (2008) Evaluation of seedling and adult plant resistance in European wheat cultivars to Australian isolates of Puccinia striiformis f. sp tritici. Euphytica 163:283-301

Peleg Z, Saranga Y, Suprunova T, Ronin Y, Roder MS, Kilian A, Korol AB, Fahima T (2008) High-density genetic map of durum wheat $\mathrm{x}$ wild emmer wheat based on SSR and DArT markers. Theor Appl Genet 117:103-115

Prins R, Pretorius ZA, Bender CM, Lehmensiek A (2011) QTL mapping of stripe, leaf and stem rust resistance genes in a Kariega $\times$ Avocet $S$ doubled haploid wheat population. Mol Breed 27:259-270

Priyamvada A, Saharan MS, Tiwari R (2011) Durable resistance in wheat. Int J Genet and Mol Biol 3(8):108-114

Quan W, Hou G, Chen J, Du Z, Lin F, Guo Y, Liu S, Zhang Z (2013) Mapping of QTL lengthening the latent period of Puccinia striiformis in winter wheat at the tillering growth stage. Eur J Plant Pathol 136:715-727

Raupp WJ, Sukhwinder S, Brown-Guedira GL, Gill BS (2001) Cytogenetic and molecular mapping of the leaf rust resistance gene Lr39 in wheat. Theor Appl Genet 102:347-352

Rehman AU, Sajjad M, Khan SH, Ahmad N (2013) Prospects of wheat breeding for durable resistance against brown, yellow and black rust fungi. Int J Agric Biol 15:1209-1220

Ren R, Wang M, Chen X, Zhang Z (2012) Characterization and molecular mapping of $Y r 52$ for high-temperature adult-plant resistance to stripe rust in spring wheat germplasm PI 183527. Theor Appl Genet 125:847-857

Revista corpoica Van der Plank JE (1963) Plant diseases: epidemics and control. Academic Press, New York, pp 1-349

Roeder MS, Korzun V, Wendehake K, Plaschke J, Tixier MH, Leroy P, Ganal MW (1998) A microsatellite map of wheat. Genetics 149:2007-2023

Rosewarne G, Singh R, Huerta-Espino J, Rebetzke G (2008) Quantitative trait loci for slow-rusting resistance in wheat to leaf rust and stripe rust identified with multi-environment analysis. Theor Appl Genet 116:1027-1034

Rosewarne GM, Singh RP, Huerta-Espino J, Herrera-Foessel SA, Forrest KL, Hayden MJ, Rebetzke GJ (2012) Analysis of leaf and stripe rust severities reveals pathotype changes and multiple minor QTLs associated with resistance in an Avocet $\mathrm{x}$ Pastor wheat population. Theor Appl Genet 124:1283-1294

Rosewarne G, Herrera-Foessel S, Singh R, Huerta-Espino J, Lan C, He Z (2013) Quantitative trait loci of stripe rust resistance in wheat. Theor Appl Genet 126:2427-2449

Rowland GG, Kerber ER (1974) Telocentric mapping in hexaploid wheat of genes for leaf rust resistance and other characters derived from Aegilops squarrosa. Can J Genet Cytol 16:137-144

Saghai Maroof MAK, Soliman RA, Jorgensen RA, Allard RW (1984) Ribosomal DNA spacer length polymorphism in barley: mendelian inheritance, chromosomal location and population dynamics. Proc Natl Acad Sci USA 81:8014-8018

SAS Institute Inc (2008) SAS/STAT ${ }^{\circledR} 9.2$ user's guide. Cary, NC

Schnurbusch T, Paillard S, Schori A, Messmer M, Schachermayr G, Winzeler M, Keller B (2004) Dissection of quantitative and durable leaf rust resistance in Swiss winter wheat reveals a major resistance QTL in the Lr34 chromosomal region. Theor Appl Genet 108:477-484

Sen S, Churchill GA (2001) A statistical framework for quantitative trait mapping. Genetics 159:371-387

Seyfarth R, Feuillet C, Schachermayr G, Winzeler M, Keller B (1999) Development of a molecular marker for the adult plant leaf rust resistance gene Lr35 in wheat. Theor Appl Genet 99:554-560

Singh RP, Dubin HJ (1997) Sustainable control of wheat diseases in wheat. Memorias Primer Simposio Internacional de Trigo, 7-9 April 1997. Cd. Obregon Sonora, Mexico, pp 93-103

Singh RP, McIntosh RA (1984) Complementary genes for reaction to Puccinia recondita tritici in Triticum aestivum I. genetic and linkage studies. Can J Genet Cytol 26:723-735

Singh R, Mujeeb-Kazi A, Huerta-Espino J (1998) Lr46: a gene conferring slow-rusting resistance to leaf rust in wheat. Phytopatholgy 88:890-894 
Singh RP, Huerta-Espino J, Rajaram S (2000a) Achieving near immunity to leaf and stripe rusts in wheat by combining slow rusting resistance genes. Acta Phytopathol Hun 35:133-139

Singh RP, Nelson JC, Sorrells ME (2000b) Mapping Yr28 and other genes for resistance to stripe rust in wheat. Crop Sci 40:1148-1155

Singh RP, Huerta-Espino J, William HM (2001) Slow rusting gene resitance to leaf and yellow rusts in wheat: genetics and breeding at CIMMYT. In: Eastwood R, Hollamby G, Rathjen T, Gororo N (eds) Assembly Proceedings of the Wheat Breeding Society of Australia Inc, Wheat Breeding Society of Australia Inc, Mildura, pp 103-108

Singh D, Simmonds J, Park RF, Bariana HS, Snape JW (2009) Inheritance and QTL mapping of leaf rust resistance in the European winter wheat 'Beaver'. Euphytica 169:253-261

Singh A, Pallavi JK, Gupta P, Prabhu KV (2011a) Identification of microsatellite markers linked to leaf rust adult plant resistance (APR) gene $L r 48$ in wheat. Plant breed 130:31-34

Singh R, Huerta-Espino J, Bhavani S, Herrera-Foessel S, Singh D, Singh P, Velu G, Mason R, Jin Y, Njau P, Crossa J (2011b) Race non-specific resistance to rust diseases in CIMMYT spring wheats. Euphytica 179:175-186

Singh D, Mohler V, Park RF (2013) Discovery, characterisation and mapping of wheat leaf rust resistance gene $\operatorname{Lr} 71$. Euphytica 190:131-136

Somers DJ, Isaac P, Edwards K (2004) A high-density microsatellite consensus map for bread wheat (Triticum aestivum L.). Theor Appl Genet 109:1105-1114

Song QJ, Shi JR, Singh S, Fickus EW, Costa JM, Lewis J, Gill BS, Ward R, Cregan PB (2005) Development and mapping of microsatellite (SSR) markers in wheat. Theor Appl Genet 110:550-560

Spielmeyer W, Sharp PJ, Lagudah ES (2003) Identification and validation of markers linked to broad-spectrum stem rust resistance gene Sr2 in wheat (Triticum aestivum L.). Crop Sci 43:333-336

Spielmeyer W, McIntosh RA, Kolmer J, Lagudah ES (2005) Powdery mildew resistance and $\operatorname{Lr} 34 / \mathrm{Yr} 18$ genes for durable resistance to leaf and stripe rust cosegregate at a locus on the short arm of chromosome 7D of wheat. Theor Appl Genet 111:731-735

Suenaga K, Singh R, Huerta-Espino J, William H (2003) Microsatellite markers for genes $\operatorname{Lr} 34 / \mathrm{Yr} 18$ and other quantitative trait loci for leaf rust and stripe rust resistance in bread wheat. Phytopatholgy 93:881-890

Van der Plank JE (1963) Plant diseases: epidemics and control. Academic Press, New York, pp 1-349

Van der Plank JE (1968) Disease resistance in plants. Academic Press, New York, pp 1-206

Voorrips RE (2002) MapChart: software for the graphical presentation of linkage maps and QTLs. J Hered 93:77-78

William HM, Hoisington D, Singh RP, Gonzalez de Leon D (1997) Detection of quantitative trait loci associated with leaf rust resistance in bread wheat. Genome 40:253-260

William M, Singh R, Huerta-Espino J, Islas S, Hoisington D (2003) Molecular marker mapping of leaf rust resistance gene $\mathrm{Lr} 46$ and its association with stripe rust resistance gene $Y r 29$ in wheat. Phytopatholgy 93:153-159

William HM, Singh RP, Huerta-Espino J, Palacios G, Suenaga K (2006) Characterization of genetic loci conferring adult plant resistance to leaf rust and stripe rust in spring wheat. Genome 49:977-990

Winzeler M, Mesterhazy A, Park R, Bartos P, Csosz M, Goyeau H, Ittu M, Jones E, Loschenberger F, Manninger K, Pasquini M, Richter K, Rubiales D, Schachermayr G, Strzembicka A, Trottet M, Unger O, Vida G, Walther U (2000) Resistance of European winter wheat germplasm to leaf rust. Agronomie 20:783-792

Xu X, Bai G, Carver B, Shaner G, Hunger R (2005a) Mapping of QTLs prolonging the latent period of Puccinia triticina infection in wheat. Theor Appl Genet 110:244-251

Xu X, Bai G, Carver B, Shaner G, Hunger R (2005b) Molecular characterization of slow leaf-rusting resistance in wheat. Crop Sci 45:758-765

Yang E, Rosewarne G, Herrera-Foessel S, Huerta-Espino J, Tang Z, Sun C, Ren Z, Singh R (2013) QTL analysis of the spring wheat 'Chapio' identifies stable stripe rust resistance despite inter-continental genotype $\mathrm{x}$ environment interactions. Theor Appl Genet 126:1721-1732

Zhao XL, Zheng TC, Xia XC, He ZH, Liu DQ, Yang WX, Yin GH, Li ZF (2008) Molecular mapping of leaf rust resistance gene LrZH84 in Chinese wheat line Zhou 8425B. Theor Appl Genet 117:1069-1075 